\title{
What evidence exists for myofunctional therapy with prefabricated appliances? A systematic review with meta-analyses of randomised trials
}

\author{
Papageorgiou, Spyridon N ; Koletsi, Despina ; Eliades, Theodore
}

\begin{abstract}
Objective: To assess the treatment efficacy/efficiency with prefabricated myofunctional appliances (PMA) for children with malocclusion. Data sources: Nine databases searched without limitations till July 2019. Data selection: Randomised trials comparing PMAs to functional appliance treatment or no treatment. Data extraction: Study selection, data extraction and risk of bias assessment were done in duplicate. Data synthesis: Random-effects meta-analyses of mean differences (MDs) or relative risks (RRs) with their 95\% confidence intervals (CIs) were conducted on seven publications (three published and one unpublished trials; 232 patients; $53 \%$ male; mean age 10.2 years). Compared to no treatment, one trial indicated that PMAs were somewhat effective in reducing overjet (MD -2.4; $95 \% \mathrm{CI}-3.3$ to -1.5 ), reducing overbite (MD -2.5 ; $95 \% \mathrm{CI}-3.2$ to -1.8 ), reducing mandibular crowding (RR 0.4; 95\% CI 0.2-0.8) and establishing Class I canine relationship ( $\mathrm{RR}=2.3 ; 95 \%$ CI 1.1-4.9). However, compared to custom-made functional appliances, three trials indicated that PMAs were less effective in reducing the ANB angle (MD 0.9; 95\% CI 0.5-1.4), increasing mandibular ramus length (MD -2.2; 95\% CI -2.9 to -1.51 ), reducing overjet (MD 1.5; 95\% CI 0.9-2.1), establishing a solid Class I molar relationship (RR 0.3 ; 95\% CI 0.2-0.7), reducing the nasolabial angle (MD 5.8; 95\% CI 0.8-10.8) and reducing facial convexity (MD -2.6 ; $95 \%$ CI -4.3 to -0.9 ). Finally, the quality of evidence was moderate to low due to risk of bias. Conclusions: PMAs are more effective in reducing overjet, overbite, mandibular crowding and establishing Class I canine relationship than no treatment. However, compared to custom-made functional appliances, PMAs are less effective in producing dental, skeletal or soft-tissue changes, even though they are less costly. Keywords: Class II malocclusion; evidence-based medicine; functional appliance; malocclusion; meta-analysis; myofunctional therapy; randomised trial; systematic review.
\end{abstract}

DOI: https://doi.org/10.1177/1465312519880558

Posted at the Zurich Open Repository and Archive, University of Zurich

ZORA URL: https://doi.org/10.5167/uzh-186124

Journal Article

Accepted Version

Originally published at:

Papageorgiou, Spyridon N; Koletsi, Despina; Eliades, Theodore (2019). What evidence exists for myofunctional therapy with prefabricated appliances? A systematic review with meta-analyses of randomised trials. Journal of Orthodontics, 46(4):297-310.

DOI: https://doi.org/10.1177/1465312519880558 


\section{TITLE PAGE \\ What evidence exists for myofunctional therapy with prefabricated appliances? A systematic review with meta-analyses of randomised trials}

Spyridon N. Papageorgiou', Despina Koletsi ${ }^{1}$, Theodore Eliades ${ }^{1}$

${ }^{1}$ Clinic of Orthodontics and Pediatric Dentistry, Center of Dental Medicine, University of Zurich, Zurich, Switzerland

Corresponding author: Spyridon N. Papageorgiou, Clinic of Orthodontics and Pediatric Dentistry, Center of Dental Medicine, University of Zurich, Plattenstrasse 11, Zurich, Switzerland; snpapage@gmail.com.

ORCIDs: S.N. Papageorgiou: 0000-0003-1968-3326 / D. Koletsi: 0000-0001-6280-9372 / T. Eliades:

0000-0003-2313-4979

Short title: Clinical evidence on myofunctional appliances

Conflicts of interest: None.

Funding: none.

Acknowledgements: We would like to thank Dr. A.F. Hanoun (Plano, TX) for providing a copy of his unpublished master thesis.

Words in abstract: 250

Words in text: 4168. 


\section{Abstract}

Objective: To assess the treatment efficacy/efficiency with Prefabricated Myofunctional Appliances (PMA) for children with malocclusion.

Data sources: Nine databases searched without limitations till July 2019.

Data selection: Randomised trials comparing PMAs to functional appliance treatment or no treatment. Data extraction: Study selection, data extraction, and risk of bias assessment were done in duplicate.

Data synthesis: Random-effects meta-analyses of Mean Differences (MDs) or Relative Risks (RRs) with their 95\% Confidence Intervals (Cls) were conducted on seven publications (3 published and 1 unpublished trials; 232 patients; 53\% male; mean age 10.2 years). Compared to no treatment, one trial indicated that PMAs were somewhat effective in reducing overjet $(\mathrm{MD}=-2.4 ; 95 \% \mathrm{Cl}=-3.3,-1.5)$, reducing overbite $(\mathrm{MD}=-$ 2.5; $95 \% \mathrm{Cl}=-3.2,-1.8)$, reducing mandibular crowding $(\mathrm{RR}=0.4 ; 95 \% \mathrm{Cl}=0.2,0.8)$, and establishing Class I canine relationship $(\mathrm{RR}=2.3 ; 95 \% \mathrm{Cl}=1.1,4.9)$. However, compared to custom-made functional appliances, 3 trials indicated that PMAs were less effective in reducing the ANB angle (MD=0.9; 95\% $\mathrm{Cl}=0.5,1.4)$, increasing mandibular ramus length $(\mathrm{MD}=-2.2 ; 95 \% \mathrm{Cl}=-2.9,-1.51)$, reducing overjet $(\mathrm{MD}=1.3$; $95 \% \mathrm{Cl}=0.6,2.0)$, establishing a solid Class I molar relationship ( $\mathrm{RR}=0.3 ; 95 \% \mathrm{Cl}=0.2,0.7)$, reducing the nasolabial angle $(\mathrm{MD}=5.8 ; 95 \% \mathrm{Cl}=0.8,10.8)$, and reducing facial convexity $(\mathrm{MD}=-2.6 ; 95 \% \mathrm{Cl}=-4.3,-0.9)$. Finally, the quality of evidence was moderate to low due to risk of bias.

Conclusions: PMAs are more effective in reducing overjet, overbite, mandibular crowding, establishing Class I canine relationship than no treatment. However, compared to custom-made functional appliances, PMAs are less effective in producing dental, skeletal, or soft-tissue changes, even though they were less costly.

Keywords: malocclusion, myofunctional therapy, functional appliance, Class II malocclusion, randomised trial, systematic review, meta-analysis, evidence-based medicine 


\section{MANUSCRIPT}

\section{Introduction}

\subsection{Background}

The interplay between soft tissue pressure from abnormal lip / tongue function, habits or respiratory problems and craniofacial development have been well documented and reported many decades ago (Moss and Rankow, 1968; Moss, 1997]. As a result, much attention has been paid to control the dentofacial growth by correcting oral dysfunction and establishing oral muscular balance (Owman-Moll and Ingervall, 1984).

Oral myofunctional therapy was introduced primarily by Rogers in the early 1900s (Cottingham, 1976), and was based on exercises aiming to establish proper oral function that would be compatible with good occlusion. A recent systematic review of however indicated that there is a lack of high-quality evidence in the existing literature regarding early orthodontic management and orofacial muscle training protocols on the correction of myofunctional and myoskeletal problems in the developing dentition (Koletsi et al., 2018). It is also important to note that Rogers considered myofunctional exercises as an aid in treatment and retention (Proffit and Mason, 1975) and not as a universal therapeutic approach for all orthodontic problems (Wishney et al., 2019).

Apart from orofacial muscle training exercises, myofunctional therapy has also including various myofunctional appliances, since the initial introduction of the oral screen in 1912 (Idris et al., 2018). Such myofunctional appliances include Prefabricated Myofunctional Appliances (PMA) like the oral shield (Cheney, 1958; Cheney, 1963), the double oral screen (Rossi et al., 1984), the Eruption Guidance Appliance (Bergersen, 1984), LM-Activator ${ }^{\mathrm{TM}}$, Myobrace ${ }^{\circledR}$, Trainer for Kids ${ }^{\mathrm{TM}}$, and Occluso-Guide ${ }^{\circledR}$. Common therapeutic protocols suggest that treatment with PMAs should be accompanied by myofunctional exercises as a part (Quadrelli et al., 2002; Tallgren et al., 1998). Some observational studies have shown that treatment with PMAs can influence oral muscle activity (Tallgren et al., 1998), reduce overjet (Tallgren et al., 1998; Quadrelli et al., 2002; Usumez et al., 2004), increase the SNB angle (Usumez et al., 2004), and increase facial height (Usumez et al., 2004). However, these studies presented several methodological limitations, including lack of an a priori registered protocol, lack of randomised treatment allocation, lack of allocation concealment, inappropriate control groups, lack of blinding, small-study effects, and reporting 
biases (Papageorgiou et al., 2014; Papageorgiou et al., 2015a; Papageorgiou et al., 2015b; Koretsi et al., 2017; Papageorgiou et al., 2018; Papageorgiou et al., 2019a).

On the other hand, randomised clinical trials in recent years (Myrlund et al., 2015; Cirgic et al., 2016; Idris et al., 2018) indicate that initial findings from observational studies or marketing claims made by manufacturers of PMAs might not be true. A recent systematic review of randomised and non-randomised studies (Mohammed et al., 2019) found that PMAs were less effective in reducing overjet of patients with Class II malocclusion in the short-term compared to custom-made Activators, but this effect was diminished in the long-term. Also, PMAs were associated with reduced costs compared to custom-made Activators. However, the inclusion of non-randomised studies might have introduced bias (Papageorgiou et al., 2015a; Papageorgiou et al., 2015b). Additionally, the clinical relevance of dental, skeletal or soft-tissue effects of PMAs on growing children needs to be assessed both in terms of absolute efficacy compared just to physiological growth, as well as in terms of relative efficacy compared to functional appliances, which are considered the gold standard for early correction of mandibular retrusion (Koretsi et al., 2015; Batista et al., 2018).

\subsection{Aim}

Aim of this systematic review was to critically appraise existing evidence from randomised trials supporting the use of PMAs for the treatment of malocclusions in children compared to other interventions or untreated controls.

\section{Materials and methods}

\subsection{Protocol and registration}

The review's protocol was registered a priori (https://osf.io/v3pjr/) and all post hoc changes were noted (Appendix 1). This review was conducted and reported according to the Cochrane Handbook (Higgins and Green, 2011) and PRISMA statement (Liberati et al., 2009), respectively.

\subsection{Eligibility criteria}


According to the Participants-Intervention-Comparison-Outcome-Study design schema, included were parallel randomised clinical trials assessing the clinical performance of PMAs administered at healthy children of any sex, ethnicity, or malocclusion compared to functional appliances treatment or no treatment. No limitations concerning language, publication year, or publication status were applied. Excluded were non-randomised studies, case series/reports, animal studies, non-longitudinal studies, non-clinical studies, animal studies, and studies on children with systemic diseases, obstructive sleep apnoea, or receiving surgery.

\subsection{Information sources and literature search}

A total of nine electronic databases were searched systematically without any limitations from inception up

to July 25th, 2019 (Appendix 2). In addition, Directory of Open Access Journals (DOAJ), Digital Dissertations (searched via UMI ProQuest), metaRegister of Controlled Trials, and Google Scholar were manually searched for additional trials. Finally, the reference/citation lists of eligible articles, as well as the reference lists of relevant reviews were checked for additional trials.

\subsection{Study selection}

Two authors (SNP, DK) screened the titles and/or abstracts of studies retrieved from the searches to identify those potentially meeting the inclusion criteria. The full text of potentially eligible trials was assessed by two authors (SNP, DK), while a third author (TE) was consulted for consensus in case of discrepancies.

\subsection{Data collection and data items}

Data collection was conducted by two authors (SNP, DK) using pre-defined forms covering: (i) study characteristics (design, clinical setting, country), (ii) patient characteristics (age, sex), (iii) malocclusion details, (iv) appliance used and any myofunctional training exercises, (v) status of treatment provider, (vi) patient compliance through treatment, (v) follow-up, and (vi) outcomes measured. Discrepancies between assessors were resolved like above, while data not provided in the article were calculated or requested from trialists (Appendix 1). 


\subsection{Risk of bias in individual trials}

The risk of bias within included trials was assessed with the new Cochrane Risk Of Bias (ROB) 2.0 tool (Sterne et al., 2019) by two authors (SNP, DK) with the same way to resolve discrepancies.

\subsection{Outcomes and data synthesis}

As the outcome of early malocclusion treatment can be affected by patient characteristics (age, growth stage, malocclusion type/severity), the type of appliance, the patient's compliance, and the patient's individual growth potential, a random-effects model was deemed appropriate to calculate the average distribution of true effects, based on clinical and statistical reasoning (Papageorgiou, 2014a). A restricted maximum likelihood random effects model was chosen a priori, based on recent guidance (Langan et al., 2019). Mean differences (MDs) for continuous outcomes and relative risks (RRs) for binary outcomes and their corresponding 95\% confidence intervals (Cls) were chosen as effect sizes, while statistically significant RRs were translated into Numbers Needed to Treat (NNTs) to gauge their clinical relevance.

Between-study heterogeneity was assessed by inspecting the forest plots and by calculating the $\mathrm{T}^{2}$ (absolute heterogeneity) and the $\mathrm{I}^{2}$ statistics (relative heterogeneity). $\mathrm{I}^{2}$ defines the proportion of total variability in the result explained by heterogeneity, but not chance. We considered arbitrarily $1^{2}$ over $75 \%$ to represent considerable heterogeneity, while also considering the heterogeneity's direction (localisation on the forest plot) and uncertainty intervals around heterogeneity estimates (Higgins et al., 2003). Ninety-five per cent predictive intervals were calculated for meta-analyses of $\geq 3$ trials to incorporate existing heterogeneity and provide a range of possible effects for a future clinical setting (IntHout et al., 2016).

All analyses were run in Stata version 14.0 (StataCorp LP, College Station, TX) by one author (SNP) and the dataset was openly provided (Papageorgiou et al., 2019b). All P values were two-sided with $\alpha=5 \%$.

\subsection{Additional analyses, risk of bias across studies, and quality of evidence}

Possible sources of heterogeneity were a priori planned to be sought through subgroup analyses and random-effects meta-regression in meta-analyses of at least 5 trials but could ultimately not be performed 
(Appendix 1). Likewise, reporting biases were planned to be assessed in meta-analyses of at least 10 trials, but could ultimately not, due to the limited number of meta-analysed trials.

The overall quality of meta-evidence (i.e. the strength of clinical recommendations) was rated using the Grades of Recommendations, Assessment, Development, and Evaluation (GRADE) approach, as very low, moderate, or high (Guyatt et al., 2011) and Summary of Findings tables were constructed using the improved format proposed by Carrasco-Labra et al. (2016). The minimal clinical important, large, and very large effects were defined as half, one, and two standard deviations of the pre-treatment measurement (for continuous outcomes) and RRs of 1.5, 2.0, and 5.0 (for binary outcomes) (Norman et al., 2003; Schünemann et al., 2009). The produced forest plots were augmented with contours denoting the magnitude of the observed effects (Papageorgiou, 2014b) to assess heterogeneity, clinical relevance, and imprecision.

\subsection{Sensitivity analyses}

Robustness of the results was planned to be checked a priori with sensitivity analyses based on (i) inclusion/exclusion of trials with low risk of bias, (ii) improvement of the GRADE classification, and (iii) inclusion/exclusion of large trials (arbitrarily set as trials with at least 30 patients/group).

\section{Results}

\subsection{Study selection}

The electronic literature search yielded 187 results, while 5 more were identified manually (Fig 1). After removal of duplicates and screening of titles / abstracts, a total of 58 articles had their full text checked against the eligibility criteria. From these 5 journal papers, one doctoral dissertation, and one master's thesis, all published in English between 2010-2018, were considered eligible for inclusion. As three papers and the doctoral dissertation pertained to the same trial, a total of 4 unique trials were finally included in this review (Appendix 3). Three included studies were published as journal papers (one also as doctoral dissertation), while a still unpublished master thesis was provided upon request (Appendix 1).

\subsection{Study characteristics}


The characteristics of the 4 included trials are presented in Table 1. Three single-centre trials were conducted in orthodontic university clinics in Malaysia, Norway, or Syria, while a multi-centre trial was conducted in twelve general dental practices in Sweden. Three of the included trials compared PMAs to functional appliances, while the fourth trial compared PMAs to an untreated control group. These 4 trials included 124 patients treated with PMAs (range 16-57; average 31) and 108 patients treated with functional appliances or left untreated (range 17-40; average 27). Male patients constituted the $53 \%$ of all included patients (123/232) and had an overall mean age of 10.2 years. Patients included in the identified trials had mostly of Class II or Class I malocclusion with increased overjet, lip incompetence, overbite, crowding, and residual growth. The used PMAs included Myobrace® (Myofunctional Research Co, Australia), Trainer For Kids ${ }^{\circledR}$ (T4K or T4F, Myofunctional Research Co, Australia), or LM-Activator (LM-Instruments Oy, Finland), while the used functional appliances included Activator or Twin Block. Treatment was provided by 12 general dentists in the multi-centre trial from Sweden, while orthodontic specialists or orthodontic residents under supervision by orthodontic specialist treated patients in the remaining 3 trials. Assessment of patient compliance with the appliances was reported only in two instances: in one case directly through patient interview or notes and in one case indirectly through treatment discontinuation or failure. Patients were followed after appliance administration for 6 months ( 1 trial), 12 months ( 2 trials), or for an undescribed period until treatment success or failure, ranging from 3.6 to 40.3 months ( 1 trial). Two trials assessed outcomes from dental casts, two from lateral cephalograms, and one assessed clinical efficacy/efficiency aspects (including time and costs).

\subsection{Risk of bias within studies}

The risk of bias of included studies is given in detail in Appendix 4 and as summary in Table 2. The single trial comparing PMAs to no treatment presented only some concerns that pertained to possible baseline imbalances and the lack of an a priori registered protocol. The three trials comparing PMAs to functional appliance all presented high risk of bias for at least one domain. The single-centre trial from Malaysia was scored as presenting some concerns mainly due to the potential issues with the reported results and the documented analysis plan. The multi-centre trial from Sweden was scored negatively for issues in the randomisation process/baseline similarity, deviations from the intended intervention, lack of blind outcome 
measurement, lack of an a priori registered protocol, and issues with the analysis/reporting of its results. Finally, the single-centre trial from Syria lacked blind outcome measurement and an a priori registered protocol.

\subsection{Results of individual studies and data synthesis}

The results of identified studies are presented separately for the comparison of PMA (LM-Activator®) versus no treatment (absolute efficacy) and separately for the comparison of various PMAs (Myobrace® or Trainer for Kids ${ }^{\circledR}$ ) versus functional appliances (relative efficacy).

As far as absolute effects of PMAs are concerned, only one included trial provided evidence on their efficacy based on analysis of dental casts (Table 3). This indicated that a 12-month treatment with PMAs was successful in reducing overjet (MD: $-2.4 \mathrm{~mm} ; 95 \% \mathrm{Cl}:-3.3$ to $-1.5 \mathrm{~mm} ; \mathrm{P}<0.001$ ) and overbite (MD: $-2.5 \mathrm{~mm} ; 95 \% \mathrm{Cl}:-1.8 \mathrm{~mm} ; \mathrm{P}<0.001)$ to a statistically and clinically relevant degree compared to no treatment. Additionally, treatment with PMAs was associated with greater percentage of patients $(63 \%$ versus $30 \%$ ) with Class I canine relationship (RR: 2.3; $95 \% \mathrm{Cl}: 1.1$ to $4.9 ; \mathrm{P}=0.03$ ) compared to no treatment. Using the NNT, this can be interpreted as every $4^{\text {th }}$ patient treated with PMA having a Class I canine relationship after 12 months that would not have if left untreated. Interestingly, no such significant benefit was seen for Class I molar relationship $(\mathrm{P}=0.16)$. Furthermore, treatment with PMAs was associated with less patients having crowding in the mandible (25\% versus $60 \%$ ) compared to no treatment (RR: 0.4 ; 95\% Cl: 0.2 to $0.8 ; P=0.02)$. According to the NNT, this meant that every $3^{\text {rd }}$ PMA patient would avoid a mandibular crowding that would exist if the patient was left untreated.

As far as relative effects of PMAs against functional appliances are concerned, three trials were identified and could contribute to meta-analyses (Table 4). Treatment with PMAs was associated with $0.9^{\circ}$ less ANB reduction ( 2 trials; $95 \% \mathrm{Cl}$ : 0.5 to $\left.1.4^{\circ} ; \mathrm{P}<0.001\right), 1.0^{\circ}$ less SNB increase ( 2 trials; $95 \% \mathrm{Cl}:-1.6$ to $\left.-0.4^{\circ} ; \mathrm{P}=0.001\right), 1.5 \mathrm{~mm}$ less overjet reduction ( $95 \% \mathrm{Cl}: 0.9$ to $\left.2.1 \mathrm{~mm} ; \mathrm{P}<0.001\right)$, and 1.4 less ANS-Me increase ( 2 trials; $95 \% \mathrm{Cl}:-2.5$ to $\left.-0.3^{\circ} ; \mathrm{P}=0.01\right)$ compared to functional appliances. All meta-analyses were homogenous $\left(\mathrm{I}^{2}=0 \%\right)$ and the magnitude of the effects was mostly small to moderate (Fig $2-3$ ). No significant differences could be found for changes in overbite, SNA, SN-ML, NL-ML, N-Me, 1s-NL, 1i-ML, and $1 \mathrm{~s}-1 \mathrm{i}$. 
Apart from these meta-analyses, 37 more outcomes were assessed by single trials and are presented in Table 5, from which only results that are both statistically significant at $5 \%$ and potentially clinically relevant are discussed here. Treatment with PMAs was associated (compared to functional appliances) with smaller Condylion-Gonion distance (+0.5 and $+2.7 \mathrm{~mm}$, respectively; MD: $-2.2 \mathrm{~mm}$; 95\% $\mathrm{Cl}$ : -2.9 to $-1.5 \mathrm{~mm})$, smaller facial convexity angle $\left(0\right.$ and $+2.6^{\circ}$, respectively; MD: $-2.6^{\circ} ; 95 \% \mathrm{Cl}:-4.3$ to $\left.0.9^{\circ}\right)$, and smaller nasolabial angle $\left(+1.8\right.$ and $-4.0^{\circ}$, respectively; MD: $5.8^{\circ} ; 95 \% \mathrm{Cl}: 0.8$ to $\left.10.8^{\circ}\right)$. Additionally, treatment with PMAs was associated with smaller percentage of patients with Class I molar relationship post-treatment (14\% versus 45\%; Fig 4) compared to functional appliances (RR: $0.3 ; 95 \% \mathrm{Cl}$ : 0.2 to 0.7$)$. Using the NNT this means that for every $4^{\text {th }}$ child treated with functional appliances instead of PMAs a Class I molar relationship is achieved, which would not be achieved if the child had been treated with PMAs. On the other hand, treatment with PMAs was associated with less visits (MD: -3.1 visits; $95 \%$ Cl: -4.6 to -1.5 visits), less chair-time (MD: -78.0 ; $95 \% \mathrm{Cl}:-113.5$ to -42.5 '), and less costs (MD: $-574.0 €$; 95\% Cl: -774.6 to $-373.5 €)$ compared to functional appliances.

\subsection{Risk of bias across studies, quality of evidence, and additional analyses}

As only a couple of trials could be ultimately included in meta-analyses, no subgroup analyses, metaregression analyses, or reporting bias analyses could be performed (Appendix 1).

The quality of existing evidence (i.e. the strength of clinical recommendations that can be formulated) was assessed with the GRADE approach (Table 6). Moderate quality of evidence supported the advantage of PMAs in terms of reduced costs and the disadvantages of PMAs in terms of worse occlusal (Class I molar relationship), skeletal (ANB angle and Cd-Go distance), and soft-tissue facial outcomes (facial convexity). This means that we can be fairly certain that the true effect is probably close to the estimated effect. On the other hand, low quality evidence supported the disadvantage of PMAs in terms of overjet reduction, which means that the true effect might be markedly different from the estimated effect and future studies might change this.

Sensitivity analyses according to bias or improvement of GRADE could likewise not be performed, since all trials presented some risk of bias and this was the reason for downgrading the quality of evidence. 
Only one sensitivity analysis according to sample size could be performed in the meta-analysis of overjet reduction by including only the top trial of Fig 3 , which gave consistent results.

\section{Discussion}

\section{1 | Summary of evidence}

The current systematic review summarizes evidence from 4 randomised trials on the clinical performance of PMAs for the treatment of children with (mostly Class II) malocclusion. The included trials moved on two major axes: comparison of PMAs to an untreated control group and comparison of PMAs to custom-made functional appliances.

As far as absolute effects of PMAs are concerned, some evidence about their efficacy was provided by a single trial from Norway (Myrlund et al., 2015). This indicated that PMAs provide clinically relevant dental effects consisting of overjet / overbite reduction, resolving of mandibular crowding and aid in establishing a Class I dental relationship at the canines. It seems that PMAs work mainly through protrusion / proclination of the lower anterior teeth and increase in the face height, which explains the corrections in overjet, overbite, crowding, and partial correction of the dental relationship only at the canine, but not the molar, while they do not significantly influence the mandibular morphology or the ANB angle. This is to some degree similar to the effects of treatment with some functional appliances. However, functional appliances are known to produce more pronounced changes in the posterior dentition and also produce significant changes in the mandibular condyles, ramus, corpus, as well as the sagittal maxilla-mandibular relationship (through the ANB angle) (Lund and Sandler, 1998; Koretsi et al., 2015; Kyburz et al., 2019). To this basis, it is important to frame any clinical recommendations about the use of PMAs for early treatment on malocclusion, on trials that directly assess the efficacy of PMAs relative to custom-made functional appliances, whose performance has been meticulously documented with ample evidence in the previous decades.

When the clinical performance of PMAs is compared to custom-made functional appliances a different picture is evident. Custom-made functional appliances have significantly more pronounced and clinically relevant effects than PMAs in terms of overjet reduction, ANB angle reduction, increase in mandibular ramus height, nasolabial angle reduction and reduction in facial convexity. Furthermore, they 
are more successful in establishing a solid Class I relationship at the molars than PMAs (45\% versus 14\%). The more favourable dentofacial picture witnessed after the use of functional appliances may due to the fact that they are custom-made appliances, which allow a precise anterior mandibular repositioning determined by the construction wax bite. Moreover, they are rigid appliances made of acrylic material which is harder than that of many PMAs like the Trainer, specifically the starting appliance (i.e. the soft blue trainer). The high elasticity of the T4K® PMA has been reported as an important flaw noted and reported by parents (Idris et al., 2018); this elasticity made it difficult for children to keep their mandibles in a forward position (i.e. in an edge-to-edge relationship at the incisors).

On the other hand, the report from a single trial shown evidence that PMAs have a clear advantage over custom-made functional appliances in terms of reduced number of treatment visits, chair-time and overall treatment costs. This is straightforward, since PMAs are prefabricated and ready to be inserted in the mouth or can be easily mouldable in warm water.

There are several factors that can influence the results of early orthodontic treatment with either PMAs or functional appliances. For example, patient compliance with instructions to wear a removable appliance has been directly linked to the attained results throughout treatment with removable appliances (Al-Kurwi et al., 2017). Patient compliance in terms of appliance wear might be checked qualitatively through interviews with the patient and treatment notes or checked quantitatively by dedicated microsensors embedded in the appliance (Schott and Ludwig, 2014), which have shown that most patients do not comply with given instructions for appliance wear time. However, criticisms about the accuracy us such sensors have been expressed (Brierley et al., 2017) and the exact amount of minimum wear time needed to produce adequate remains debatable (Parekh et al., 2019). In the present review, only two of the included trials assessed in any way patient compliance with appliance wear, but only through indirect means and this cannot be taken formally into account.

Another factor that might influence the diagnosis, choice of treatment, and outcome of early orthodontic treatment is the training, knowledge, and expertise of the treatment provider (Akyalcin, 2019). Orthodontists and orthodontic residents are certainly trained to make better judgements about case complexity compared to general dentists, based on objective severity indices, which indicates that additional orthodontic education has an influence on the ability to arrive to better assessment of the case 
and diagnosis (Heath et al., 2017). Another study (Marques et al., 2012) indicated that $50 \%$ of general dentists would fail the American Board of Orthodontists objective outcome evaluation of a case they considered best representative of their clinical practice. Interceptive treatment for posterior crossbites, managed by orthodontic specialists, has been reported to achieve higher success rate and lower treatment costs compared to treatment by general dentists (Sollenius et al., 2019). This agrees with a previous study from Finland, which indicated that general dentists with little orthodontic experience usually overrate their provided orthodontic care to their patients (Pietilä et al., 1998). In the present review one trial employed 12 general dentists for the early correction of Class II malocclusion with PMAs or functional appliances, but no information was given about systematic differences among the different trial centres or about the training, expertise, and calibration of the treatment providers, which might have influenced the trial's results.

\section{2 | Strengths and limitations}

This systematic review has several strengths, which include its a priori registered protocol (https://osf.io/v3pjr/), its comprehensive literature search, the sole inclusion of randomised trials (Papageorgiou et al., 2015a; Papageorgiou et al., 2015b), the use of modern analytic methods (Langan et al., 2019), application of the GRADE approach to assess the strength of provided recommendations (Guyatt et al., 2011), and the transparent provision of all data (Papageorgiou and Cobourne, 2018; Papageorgiou et al., 2019a). Finally, this review builds up on the recommendation from a previous systematic review of randomised and non-randomised studies (Mohammed et al., 2019) that reported that PMAs were less effective in reducing overjet but had significantly less treatment costs. The current review retains the superiority of functional appliances for overjet reduction, but extends this further to additional various dental, skeletal, and soft-tissue effects. Therefore, concrete differences in the efficacy and mode of treatment were seen between PMAs and functional appliances, which potentially undermine the suggested advantage of reduced costs for PMAs.

At the same time, some limitations also exist in the present review. First, both performed metaanalyses were based predominantly on small trials, which might affect their results (Cappelleri et al., 1996; Papageorgiou et al., 2014). Second, most trials assessed treatment effects after 6-12 months of treatment and not on the long term, when any catch-up growth effects might be observed. Finally, the small number 
of trials that were ultimately included in the meta-analyses and their poor reporting of potential confounders precluded the conduct of analyses for subgroups, meta-regressions, and reporting bias that were initially planned (Appendix 1).

\section{Conclusions}

The current systematic review summarizes evidence from 4 randomised trials with 232 patients on the clinical performance of PMAs for the treatment of children with (mostly Class II) malocclusion. According to evidence of moderate to low quality, the following can be concluded:

- Compared to no treatment, PMAs seem to be effective in alleviating Class II malocclusion and mandibular crowding, which is mainly achieved through dentoalveolar effects (proclination of the lower incisors).

- Compared to orthodontic treatment with functional appliances, PMAs are significantly less effective in treating Class II malocclusion through dentoalveolar effects and have significantly less potential to modify skeletal growth or improve the facial profile, even though they associated with significantly lower treatment costs.

- Many of the claims made by manufacturers of PMAs about their clinical effect are unsubstantiated by up to date high quality evidence.

- There is currently no evidence for the relative performance of the different PMAs or for any patientor treatment-related factors that might influence treatment outcome.

Therefore, even though PMAs might have some potentially beneficial characteristics, they cannot be suggested in an evidence-based manner as a regular early and solely treatment of malocclusion over conventional orthodontic treatment. 


\section{References}

Akyalcin S (2019) Specialist training influences the ability to recognize orthodontic case complexity. Journal of Orthodontics 46(1_suppl): 35-38.

Al-Kurwi AS, Bos A and Kuitert RB (2017) Overjet reduction in relation to wear time with the van Beek activator combined with a microsensor. American Journal of Orthodontics and Dentofacial Orthopedics 151: 277-283.

Batista KB, Thiruvenkatachari B, Harrison JE and O'Brien KD (2018) Orthodontic treatment for prominent upper front teeth (Class II malocclusion) in children and adolescents. Cochrane Database of Systematic Reviews 3: CD003452.

Bergersen EO (1984) The eruption guidance myofunctional appliances: how it works, how to use it. The Functional Orthodontist 1: 28-29.

Brierley CA, Benson PE and Sandler J (2017) How accurate are TheraMon® microsensors at measuring intraoral wear-time? Recorded vs. actual wear times in five volunteers. Journal of Orthodontics 44: 241-248.

Cappelleri JC, loannidis JP, Schmid CH, de Ferranti SD, Aubert M, Chalmers TC, et al. (1996) Large trials vs meta-analysis of smaller trials: how do their results compare? JAMA 276: 1332-1338.

Carrasco-Labra A, Brignardello-Petersen R, Santesso N, Neumann I, Mustafa RA, Mbuagbaw L, et al. (2016) Improving GRADE evidence tables part 1: a randomized trial shows improved understanding of content in summary of findings tables with a new format. Journal of Clinical Epidemiology 74: 718.

Cheney EA (1958) Factors in the early treatment and interception of malocclusion. American Journal of Orthodontics 44: 807-826.

Cheney EA (1963) Treatment planning and therapy in the mixed dentition. American Journal of Orthodontics 49: 568-580.

Cirgic E, Kjellberg H and Hansen K (2016) Treatment of large overjet in Angle Class II: division 1 malocclusion with Andresen activators versus prefabricated functional appliances-a multicenter, randomized, controlled trial. European Journal of Orthodontics 38: 516-524. 
Cottingham LL (1976) Myofunctional therapy. Orthodontics--tongue thrusting-speech therapy. American Journal of Orthodontics 69: 679-687.

Guyatt GH, Oxman AD, Schünemann HJ, Tugwell P and Knottnerus A (2011) GRADE guidelines: a new series of articles in the Journal of Clinical Epidemiology. Journal of Clinical Epidemiology 64: 380382.

Heath EM, English JD, Johnson CD, Swearingen EB and Akyalcin S (2017) Perceptions of orthodontic case complexity among orthodontists, general practitioners, orthodontic residents, and dental students. American Journal of Orthodontics and Dentofacial Orthopedics 151: 335-341.

Higgins JP, Thompson SG, Deeks JJ and Altman DG (2003) Measuring inconsistency in meta-analyses. BMJ 327: 557-560.

Higgins JPT and Green S (2011) Cochrane handbook for systematic reviews of interventions. Version 5.1.0 (updated March 2011). The Cochrane Collaboration, 2011. Retrieved from http://www.cochranehandbook.org

IntHout J, loannidis JPA, Rovers MM and Goeman JJ (2016) Plea for routinely presenting prediction intervals in meta-analysis. BMJ Open 6: e010247.

Koletsi D, Makou M and Pandis N (2018) Effect of orthodontic management and orofacial muscle training protocols on the correction of myofunctional and myoskeletal problems in developing dentition. A systematic review and meta-analysis. Orthodontics and Craniofacial Research 21: 202-215.

Koretsi V, Eliades T and Papageorgiou SN (2018) Oral Interventions for Obstructive Sleep Apnea. Deutsches Arzteblatt International 115: 200-207.

Koretsi V, Zymperdikas VF, Papageorgiou SN and Papadopoulos MA (2015) Treatment effects of removable functional appliances in patients with Class II malocclusion: a systematic review and meta-analysis. European Journal of Orthodontics 37: 418-434.

Kyburz KS, Eliades T and Papageorgiou SN (2019) What effect does functional appliance treatment have on the temporomandibular joint? A systematic review with meta-analysis. Progress in Orthodontics [Epub ahead of print]. doi: 10.1186/s40510-019-0286-9. 
Langan D, Higgins JPT, Jackson D, Bowden J, Veroniki AA, Kontopantelis E, et al. (2019) A comparison of heterogeneity variance estimators in simulated random-effects meta-analyses. Research Synthesis Methods 10: 89-98.

Liberati A, Altman DG, Tetzlaff J, Mulrow C, Gøtzsche PC, loannidis JP, et al. (2009) The PRISMA statement for reporting systematic reviews and meta-analyses of studies that evaluate health care interventions: explanation and elaboration. Journal of Clinical Epidemiology 62: e1-34.

Lund DI and Sandler PJ (1998) The effects of Twin Blocks: a prospective controlled study. American Journal of Orthodontics and Dentofacial Orthopedics 113: 104-110.

Marques LS, Freitas Junior Nd, Pereira LJ and Ramos-Jorge ML (2012) Quality of orthodontic treatment performed by orthodontists and general dentists. The Angle Orthodontist 82: 102-106.

Mohammed H, Čirgić E, Rizk MZ and Vandevska-Radunovic V (2019) Effectiveness of prefabricated myofunctional appliances in the treatment of Class II division 1 malocclusion: a systematic review. European Journal of Orthodontics 2019 [Epub ahead of print]. doi:10.1093/ejo/cjz025.

Moss ML (1997) The functional matrix hypothesis revisited. 1. The role of mechanotransduction. American Journal of Orthodontics and Dentofacial Orthopedics 112: 8-11.

Moss ML and Rankow RM (1968) The role of the functional matrix in mandibular growth. The Angle Orthodontist 38: 95-103.

Myrlund R, Dubland M, Keski-Nisula K and Kerosuo H (2015) One year treatment effects of the eruption guidance appliance in 7- to 8-year-old children: a randomized clinical trial. European Journal of Orthodontics 37: 128-134.

Norman GR, Sloan JA and Wyrwich KW (2003) Interpretation of Changes in Health-related Quality of Life. Medical Care 41: 582-592.

Owman-Moll P and Ingervall B (1984) Effect of oral screen treatment on dentition, lip morphology, and function in children with incompetent lips. American Journal of Orthodontics 85: 37-46.

Papageorgiou SN (2014a). Meta-analysis for orthodontists: Part l--How to choose effect measure and statistical model. Journal of Orthodontics 41: 317-326.

Papageorgiou SN (2014b) Meta-analysis for orthodontists: Part II--Is all that glitters gold? Journal of Orthodontics 41: 327-336. 
Papageorgiou SN and Cobourne MT (2018) Data sharing in orthodontic research. Journal of Orthodontics 45: 1-3.

Papageorgiou SN, Antonoglou GN, Martin C and Eliades T (2019a) Methods, transparency and reporting of clinical trials in orthodontics and periodontics. Journal of Orthodontics 46: 101-109.

Papageorgiou SN, Antonoglou GN, Sándor GK and Eliades T (2017a) Randomized clinical trials in orthodontics are rarely registered a priori and often published late or not at all. PLoS One 12: e0182785.

Papageorgiou SN, Antonoglou GN, Tsiranidou E, Jepsen S and Jäger A (2014) Bias and small-study effects influence treatment effect estimates: a meta-epidemiological study in oral medicine. Journal of Clinical Epidemiology 67: 984-992.

Papageorgiou SN, Höchli D and Eliades T (2017b) Outcomes of comprehensive fixed appliance orthodontic treatment: A systematic review with meta-analysis and methodological overview. Korean Journal of Orthodontics 47: 401-413.

Papageorgiou SN, Kloukos D, Petridis H and Pandis N (2015a) Publication of statistically significant research findings in prosthodontics \& implant dentistry in the context of other dental specialties. Journal of Dentistry 43: 1195-1202.

Papageorgiou SN, Koletsi D and Eliades T (2019b) What evidence exists for myofunctional therapy with prefabricated appliances? A systematic review with meta-analyses of randomized trials [dataset]. [Data set]. Zenodo. http://doi.org/10.5281/zenodo.3358548.

Papageorgiou SN, Koretsi V and Jäger A (2017c) Bias from historical control groups used in orthodontic research: a meta-epidemiological study. European Journal of Orthodontics 39: 98-105.

Papageorgiou SN, Xavier GM and Cobourne MT (2015b) Basic study design influences the results of orthodontic clinical investigations. Journal of Clinical Epidemiology 68: 1512-22.

Papageorgiou SN, Xavier GM, Cobourne MT and Eliades T (2018) Registered trials report less beneficial treatment effects than unregistered ones: a meta-epidemiological study in orthodontics. Journal of Clinical Epidemiology 100: 44-52. 
Parekh J, Counihan K, Fleming PS, Pandis N and Sharma PK (2019) Effectiveness of part-time vs full-time wear protocols of Twin-block appliance on dental and skeletal changes: A randomized controlled trial. American Journal of Orthodontics and Dentofacial Orthopedics 155: 165-172.

Pietilä T, Sintonen H, Pietilä I, Widström E, Varrela J and Alanen P (1998) Cost and productivity analysis of orthodontic care in Finland. Community Dentistry Oral Epidemiology 26: 283-288.

Proffit WR and Mason RM (1975) Myofunctional therapy for tongue-thrusting: background and recommendations. Journal of the American Dental Association 90: 403-411.

Quadrelli C, Gheorgiu M, Marcheti C and Ghiglione V (2002) Early myofunctional approach to skeletal Class II. Mondo Ortodontico 2: 109-122.

Rossi R, Mortara MC and Boccaccio E (1984) Preventive orthodontics and the use of oral screens. Parodontologia e Stomatologia (Nuova) 23(Suppl 3): 191-192.

Schott TC and Ludwig B (2014) Microelectronic wear-time documentation of removable orthodontic devices detects heterogeneous wear behavior and individualizes treatment planning. American Journal of Orthodontics and Dentofacial Orthopedics 146: 155-160.

Schünemann H, Brozek J and Oxman A (2009) GRADE handbook for grading quality of evidence and strength of recommendation. version 3. The GRADE Working Group, 2009. https://gradepro.org/handbook/

Sideri S, Papageorgiou SN and Eliades T (2017) Are orthodontic systematic reviews registered a priori in PROSPERO? Journal of Orthodontics 44: 249-255.

Sideri S, Papageorgiou SN and Eliades T (2018) Registration in the international prospective register of systematic reviews (PROSPERO) of systematic review protocols was associated with increased review quality. Journal of Clinical Epidemiology 100: 103-110.

Sollenius O, Petrén S and Bondemark L (2019) An RCT on clinical effectiveness and cost analysis of correction of unilateral posterior crossbite with functional shift in specialist and general dentistry. European Journal of Orthodontics. doi:10.1093/ejo/cjz014. [Epub ahead of print].

Sterne JAC, Savović J, Page MJ, Elbers RG, Blencowe NS, Boutron I, et al. (2019) RoB 2: a revised tool for assessing risk of bias in randomised trials. BMJ 366: 14898. 
Tallgren A, Christiansen RL, Ash M Jr and Miller RL (1998) Effects of a myofunctional appliance on orofacial muscle activity and structures. The Angle Orthodontist 68: 249-258.

Usumez S, Uysal T, Sari Z, Basciftci FA, Karaman Al and Guray E (2004) The effects of early preorthodontic trainer treatment on Class II, division 1 patients. The Angle Orthodontist 74: 605-609. 


\section{Figure Legends}

Fig 1. PRISMA flowdiagram for the identification and selection of studies eligible in this review.

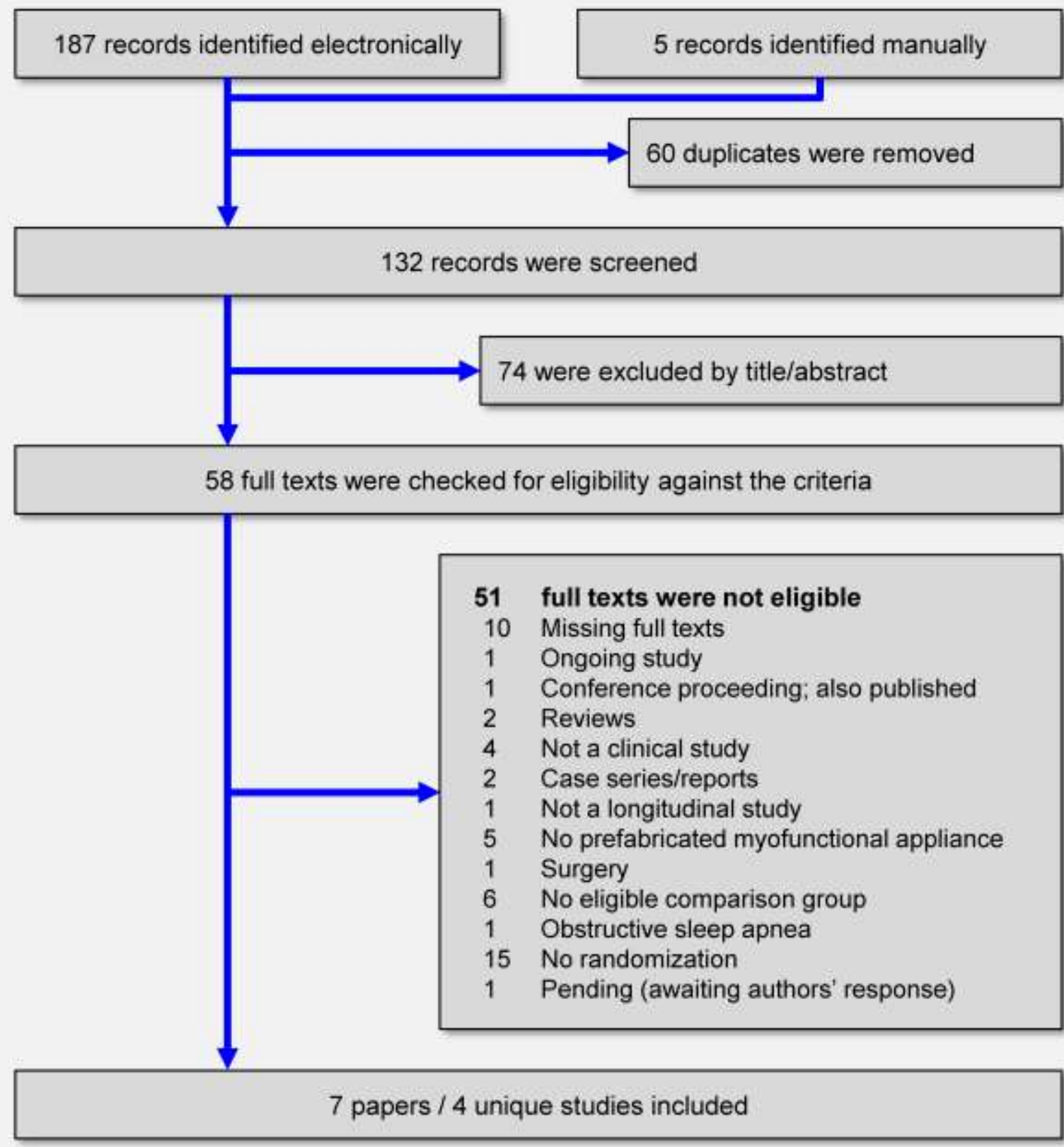


Fig 2. Contour-enhanced forest plot on the treatment effects of prefabricated myofunctional appliances versus functional appliances for change in ANB angle. Cl, confidence interval; MD, mean difference; PMA, prefabricated myofunctional appliance; SD, standard deviation.

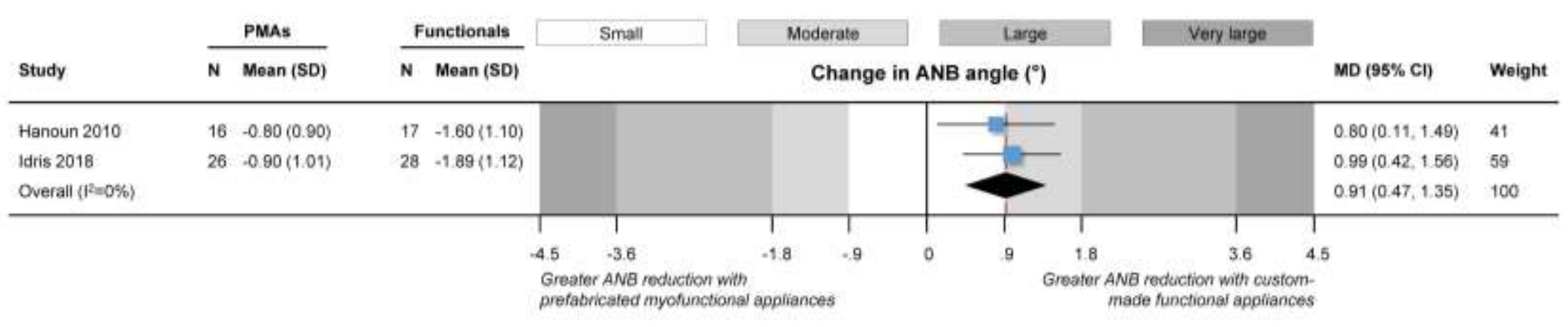


Fig 3. Contour-enhanced forest plot on the treatment effects of prefabricated myofunctional appliances versus functional appliances for change in overjet. $\mathrm{Cl}$, confidence interval; MD, mean difference; PMA, prefabricated myofunctional appliance; SD, standard deviation.

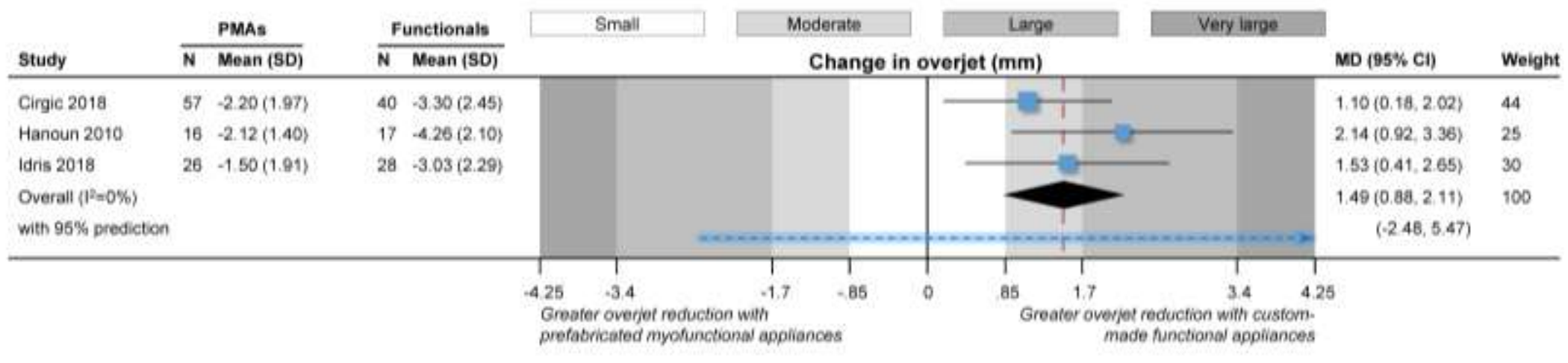


Fig 4. Expected relative frequency of people with Class I molar relationship post treatment with prefabricated myofunctional appliances versus functional appliances.

\section{Functional appliance Class I molar relationship post- $\mathrm{TX}=\mathbf{4 5 . 0 \%}$}

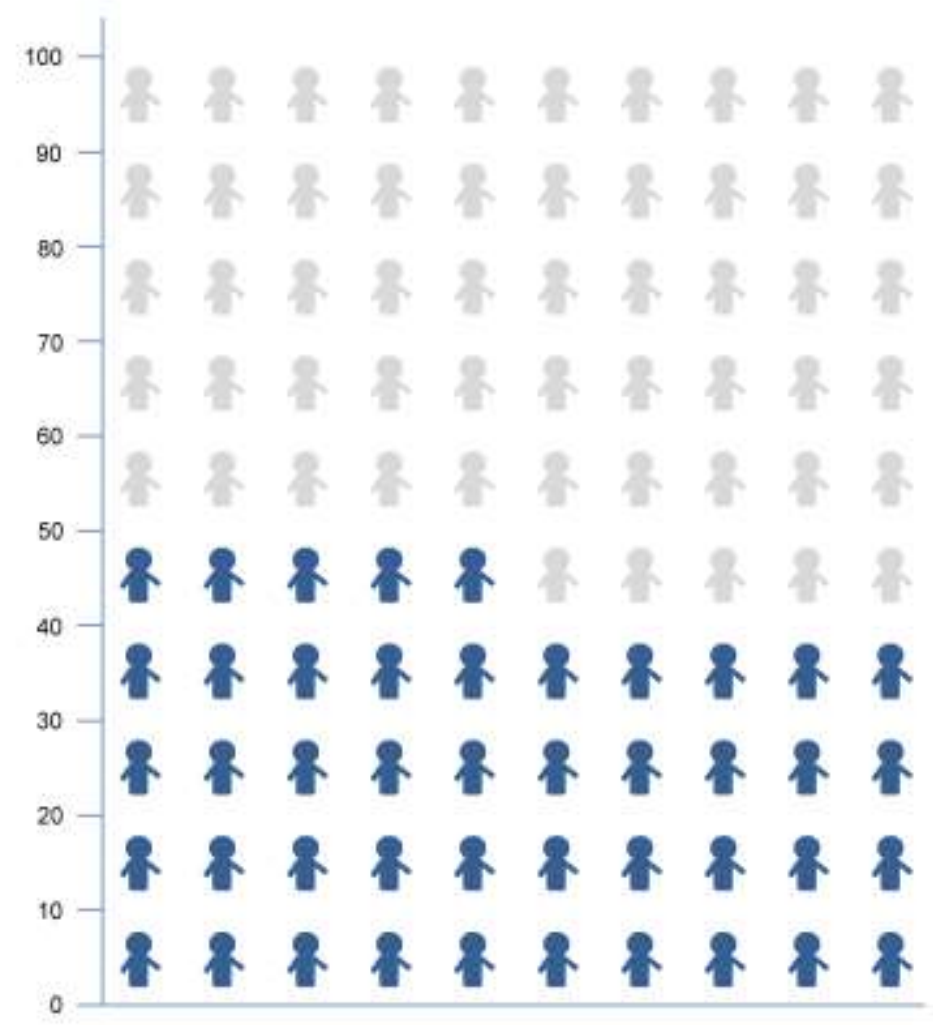

Prefabricated Myofunctional Appliance Class I molar relationship post- $\mathrm{Tx}=14.0 \%$

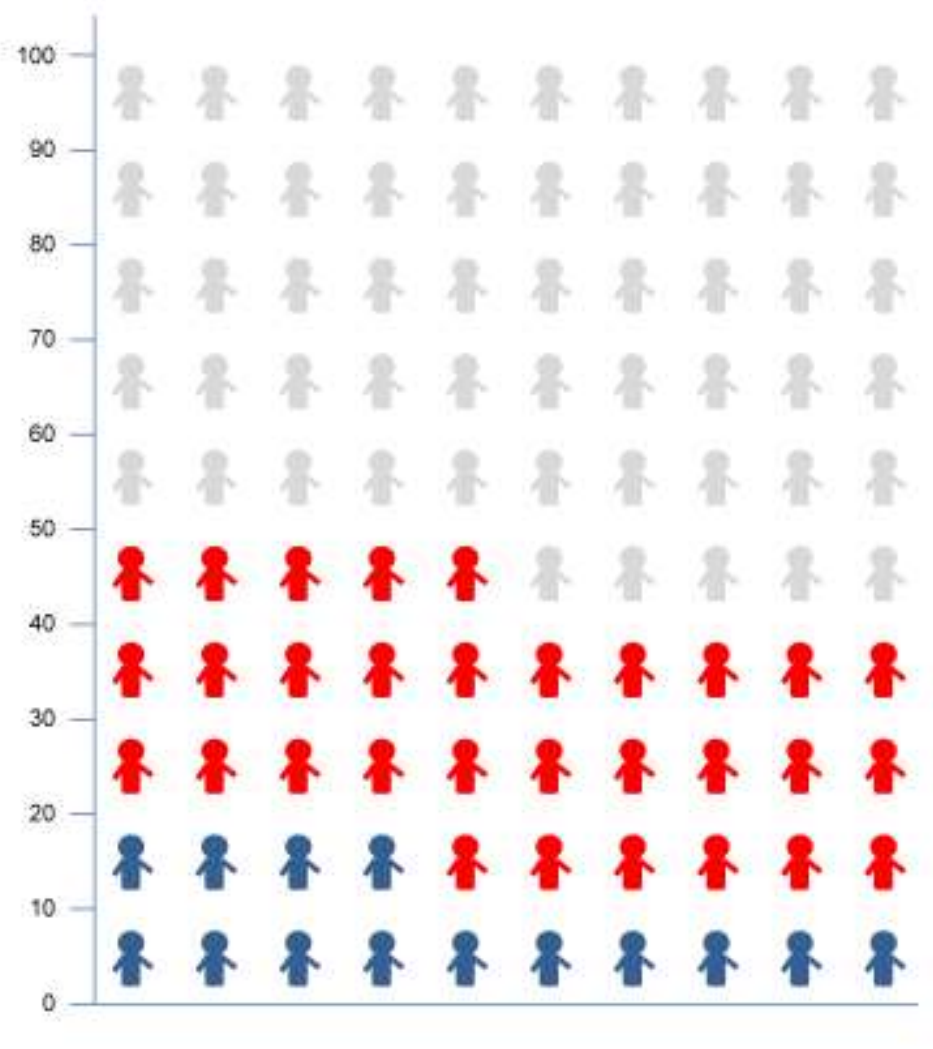




\section{TABLES}

Table 1. Characteristics of included studies.

\begin{tabular}{|c|c|c|c|c|c|c|c|c|}
\hline Study & $\begin{array}{l}\text { Design; } \\
\text { setting; } \\
\text { country* }\end{array}$ & Patients (M/F); age ${ }^{\dagger}$ & Malocclusion / Tx & Appliance & $\begin{array}{l}\text { Provide } \\
\mathbf{r}\end{array}$ & Compliance & FU & Outcome \\
\hline $\begin{array}{l}\text { Cirgic } \\
2016 ; \\
2017 a-c\end{array}$ & $\begin{array}{l}\text { RCT; } \\
\text { Clinic; } \\
\text { SWE }\end{array}$ & $\begin{array}{l}\text { PMA: } 57 \text { (29/28); NR } \\
\text { RFA: } 40 \text { (24/16); NR } \\
\text { (overall age: } 10.3 \text { ) }\end{array}$ & $\begin{array}{l}\text { Class II } / 1 ; \text { OJ>6mm or } \\
\text { lip incompetence }\end{array}$ & $\begin{array}{l}\text { PMA: Myobrace }{ }^{\circledR} \\
\text { RFA: Activator (mod) }\end{array}$ & GP & $\begin{array}{l}\text { Through } \\
\text { discontinuati } \\
\text { on / Tx } \\
\text { failure }\end{array}$ & $\begin{array}{l}\text { T1: 3.6- } \\
40.3 \\
\text { mos } \\
\text { T2: T1 }+ \\
12 \text { mos }\end{array}$ & $\begin{array}{l}\text { Casts: OB; OJ; sagMR } \\
\text { Clinical: Chairtime; costs; } \\
\text { LiSe; Re-Tx need; Tx } \\
\text { duration; Tx success; } \\
\text { visits }\end{array}$ \\
\hline $\begin{array}{l}\text { Hanoun } \\
2010\end{array}$ & $\begin{array}{l}\text { RCT; Uni; } \\
\text { MYS }\end{array}$ & $\begin{array}{l}\text { PMA: } 16(9 / 7) ; 13.0 \\
\text { RFA: } 17(8 / 9) ; 13.2\end{array}$ & Class II/1; OJ $\geq 7 \mathrm{~mm}$ & $\begin{array}{l}\text { PMA: T4F® } \\
\text { RFA: Twin Block }\end{array}$ & Ortho & NR & $6 \mathrm{mos}$ & $\begin{array}{l}\text { LC: various skeletal, } \\
\text { dental, and soft-tissue } \\
\text { parameters }\end{array}$ \\
\hline $\begin{array}{l}\text { Idris } \\
2018\end{array}$ & $\begin{array}{l}\text { RCT; Uni; } \\
\text { SYR }\end{array}$ & $\begin{array}{l}\text { PMA: } 26(14 / 12) ; 10.3 \\
\text { RFA: } 28(14 / 14) ; 10.6\end{array}$ & $\begin{array}{l}\text { Class II } / 1 ; \text { OJ>4mm; } \\
\text { ANB }>4^{\circ} ; \text { Wits }>2 \mathrm{~mm} \\
\text { before/at growth spurt } \\
\text { (HWR: PP2=, MP3 }=, S \\
\text { stages) }\end{array}$ & $\begin{array}{l}\text { PMA: T4K® + } \\
\text { exercises } \\
\text { RFA: Activator }\end{array}$ & Ortho & NR & $12 \mathrm{mos}$ & $\begin{array}{l}\text { LC: various skeletal, } \\
\text { dental, and soft-tissue } \\
\text { parameters }\end{array}$ \\
\hline $\begin{array}{l}\text { Myrlund } \\
2015\end{array}$ & $\begin{array}{l}\text { RCT; Uni; } \\
\text { NOR }\end{array}$ & $\begin{array}{l}\text { PMA: } 25 \text { (13/12); } 7.7 \\
\text { CTR: } 23 \text { (12/11); } 7.7\end{array}$ & $\begin{array}{l}\text { Class I or II with: } \\
\text { (i) deepbite or (ii) } \\
\text { OJ } \geq 5 \mathrm{~mm} \text { or (iii) } \\
\text { moderate crowding } \\
\text { with OJ } \geq 4 \mathrm{~mm}\end{array}$ & $\begin{array}{l}\text { PMA: LM-Activator }{ }^{T M} \\
\text { CTR: No Tx }\end{array}$ & Ortho & $\begin{array}{l}\text { From FU } \\
\text { interview and } \\
\text { patient notes }\end{array}$ & $12 \mathrm{mos}$ & $\begin{array}{l}\text { Casts: OJ; OB; sagCR; } \\
\text { sagMR; crowding }{ }^{\ddagger}\end{array}$ \\
\hline
\end{tabular}

${ }^{*}$ countries given with their alpha-3 codes.

† patient age is given either mean.

¥ various skeletal, dental, and soft-tissue parameters were assessed from lateral cephalograms, but only in the PMA group, and are therefore not listed here.

CTR, control group; FU, follow-up; GP, general practitioner; HWR, hand wrist radiograph; LC, lateral cephalogram; LiSe, lip seal; M/F, male / female; mo, month; mod, modified; NR, not reported; OB, overbite; OJ, overjet; Ortho, orthodontist or orthodontic resident under supervision of orthodontist; PMA, prefabricated myofunctional appliance; RCT, randomised clinical trial; RFA, removable functional appliance; sagCR, sagittal canine relationship;

sagMR, sagittal molar relationship; Tx, treatment; Uni, university clinic; yr, year. 
Table 2. Risk of bias of included trials.

\begin{tabular}{|l|l|l|l|l|l|l|l|}
\hline $\mathbf{N r}$ & Reference & $\begin{array}{l}\text { Randomisation } \\
\text { process }\end{array}$ & $\begin{array}{l}\text { Deviations } \\
\text { from intended } \\
\text { interventions }\end{array}$ & $\begin{array}{l}\text { Mising } \\
\text { outcome } \\
\text { data }\end{array}$ & $\begin{array}{l}\text { Measurement } \\
\text { of the } \\
\text { outcome }\end{array}$ & $\begin{array}{l}\text { Selection of the } \\
\text { reported result }\end{array}$ & Overall \\
\hline 1 & Cirgic 2016 & Some concerns & High & Low & High & High & High \\
\hline 2 & Hanoun 2010 & Low & Low & Low & Low & Some concerns & Some concerns \\
\hline 3 & Idris 2018 & Low & Low & Low & High & Some concerns & High \\
\hline 4 & Myrlund 2015 & Low & Low & Low & Low & Some concerns & Some concerns \\
\hline
\end{tabular}

Table 3. Outcomes assessed by the single included trial comparing prefabricated myofunctional appliances with no treatment. Results pertain to post-treatment values, since no increments were given and not other similar trials were included to calculate pre/post correlations.

\begin{tabular}{|c|c|c|c|c|c|c|}
\hline $\mathrm{Nr}$ & Trial & Outcome & Effect $(95 \% \mathrm{Cl})$ & $\mathbf{P}$ & $1 / 2$ SD & Clinically relevant $^{*}$ \\
\hline 1 & Myrlund 2015 & Overjet (mm) & MD:-2.40 (-3.27, -1.53) & $<0.001$ & 0.65 & Yes \\
\hline 2 & Myrlund 2015 & Overbite (mm) & MD: $-2.50(-3.19,-1.81)$ & $<0.001$ & 0.70 & Yes \\
\hline 3 & Myrlund 2015 & Class I molar relationship & RR:1.53 $(0.85,2.76)$ & 0.16 & - & - \\
\hline 4 & Myrlund 2015 & Class I canine relationship & RR:2.29 (1.08, 4.85) & 0.03 & - & Yes \\
\hline 5 & Myrlund 2015 & Crowding (maxilla) & RR:0.92 $(0.55,1.52)$ & 0.74 & - & - \\
\hline 6 & Myrlund 2015 & Crowding (mandible) & RR:0.39 $(0.18,0.84)$ & 0.02 & - & Yes \\
\hline
\end{tabular}

\section{$\mathrm{Cl}$, confidence interval; MD, mean difference; RR, relative risk; SD, standard deviation.}

* potentially clinically relevant effect, judged as an effect that is statistically significant $(P<0.05)$ and its effect is at least as big as the minimal clinical important effect: half a standard deviation (combined pre-treatment standard deviation of the two groups) or relative risk $\geq 1.50$ (or $\leq 0.67$ ). 
Table 4. Results of the random-effects meta-analyses comparing prefabricated myofunctional appliances with functional appliances. Results pertain to treatmentrelated reductions (increments) and positive MD indicate smaller reductions with prefabricated myofunctional appliances.

\begin{tabular}{|c|c|c|c|c|c|c|}
\hline Outcome & Trials & MD (95\% Cl) & $\mathbf{P}$ & $I^{2}(95 \% \mathrm{Cl})$ & $\mathrm{T}^{2}(95 \% \mathrm{Cl})$ & 95\% Prl \\
\hline Overjet & 3 & $1.50(0.88,2.11)$ & $<0.001^{*}$ & $0 \%(0 \%, 94 \%)$ & $0(0,4.53)$ & $-2.48,5.47$ \\
\hline Overbite & 2 & $0.64(-0.08,1.36)$ & 0.08 & $0 \%(0 \%, 98 \%)$ & $0(0,17.43)$ & - \\
\hline SNA & 2 & $-0.11(-0.66,0.44)$ & 0.70 & $0 \%(0 \%, 99 \%)$ & $0(0,24.98)$ & - \\
\hline SNB & 2 & $-1.04(-1.64,-0.43)$ & $0.001^{*}$ & $0 \%(0 \%, 98 \%)$ & $0(0,13.26)$ & - \\
\hline ANB & 2 & $0.91(0.48,1.35)$ & $<0.001^{*}$ & $0 \%(0 \%, 99 \%)$ & $0(0,5.61)$ & - \\
\hline SN-ML & 2 & $0.16(-0.68,1.01)$ & 0.70 & $0 \%(0 \%, 98 \%)$ & $0(0,22.24)$ & - \\
\hline NL-ML & 2 & $0.53(-0.39,1.45)$ & 0.26 & $0 \%(0 \%, 98 \%)$ & $0(0,20.69)$ & - \\
\hline $\mathrm{N}-\mathrm{Me}$ & 2 & $-1.73(-4.91,1.46)$ & 0.29 & $77 \%(0 \%, 100 \%)$ & $4.04(0,662.35)$ & - \\
\hline ANS-Me & 2 & $-1.39(-2.50,-0.28)$ & $0.01^{*}$ & $0 \%(0 \%, 98 \%)$ & $0(0,33.04)$ & - \\
\hline 1s-NL & 2 & $0.44(-0.63,1.50)$ & 0.42 & $28 \%(0 \%, 99 \%)$ & $0.24(0,108.84)$ & - \\
\hline 1i-ML & 2 & $0.09(-1.47,1.64)$ & 0.91 & $21 \%(0 \%, 99 \%)$ & $0.31(0,189.01)$ & - \\
\hline 1s-1i & 2 & $-0.84(-3.38,1.71)$ & 0.52 & $0 \%(0 \%, 99 \%)$ & $0(0,226.98)$ & - \\
\hline
\end{tabular}

\begin{tabular}{lll}
$1 \mathrm{~S}-1 \mathrm{i}$ & 2 & $-0.84(-3.38,1.71)$ \\
\hline $\mathrm{Cl}$, confidence interval; $\mathrm{MD}$, mean difference
\end{tabular}

* statistically significant at the $5 \%$ level 
Table 5. Treatment-related changes assessed by single included studies. Omitted are the outcome of ANB angle and overjet, since they are included in the meta-analyses of Table 4.

\begin{tabular}{|c|c|c|c|c|c|c|}
\hline $\mathrm{Nr}$ & Trial & Outcome & Effect $(95 \% \mathrm{Cl})$ & $\mathbf{P}$ & $1 / 2$ SD & $\begin{array}{l}\text { Clinically } \\
\text { relevant }^{\star}\end{array}$ \\
\hline 1 & Cirgic 2016 & Class I molar relationship & RR:0.31 (0.15,0.65) & 0.002 & & Yes \\
\hline 2 & Cirgic 2016 & Number of visits & MD:-3.05 (-4.60,-1.50) & $<0.001$ & 2.05 & Yes \\
\hline 3 & Cirgic 2016 & Emergency visits & MD:-0.60 (-0.90,-0.30) & $<0.001$ & 0.45 & Yes \\
\hline 4 & Cirgic 2016 & Chair time (min) & MD:-78.00 (-113.54,-42.46) & $<0.001$ & 50.00 & Yes \\
\hline 5 & Cirgic 2016 & Direct costs-material & MD:-152.00 (-175.57,-128.43) & $<0.001$ & 37.50 & Yes \\
\hline 6 & Cirgic 2016 & Direct costs-chair time & MD:-274.00 (-399.38,-148.62) & $<0.001$ & 176.50 & Yes \\
\hline 7 & Cirgic 2016 & Indirect costs & MD:-148.00 (-212.69,-83.31) & $<0.001$ & 88.00 & Yes \\
\hline 8 & Cirgic 2016 & Societal (total) costs & MD:-574.00 (-774.55,-373.45) & $<0.001$ & 284.50 & Yes \\
\hline 9 & Cirgic 2016 & Treatment failure (residual overjet $>3 \mathrm{~mm}$ ) & RR:1.34 (0.95,1.88) & 0.09 & & - \\
\hline 10 & Cirgic 2016 & Retreatment need & RR:1.64 (0.69,3.90) & 0.27 & & - \\
\hline 11 & Cirgic 2016 & Treatment duration & MD:-2.64 (-5.77,0.49) & 0.10 & & - \\
\hline 12 & Hanoun 2010 & $\operatorname{Ar}-\mathrm{A}(\mathrm{mm})$ & MD:0.16 (-0.57,0.89) & 0.67 & 1.74 & - \\
\hline 13 & Hanoun 2010 & $\operatorname{Ar}-\mathrm{B}(\mathrm{mm})$ & MD:-0.57 $(-2.10,0.96)$ & 0.46 & 2.49 & - \\
\hline 14 & Hanoun 2010 & $\operatorname{Ar}-\operatorname{Pog}(\mathrm{mm})$ & MD:-0.64 (-2.27,0.99) & 0.44 & 2.73 & - \\
\hline 15 & Hanoun 2010 & Sella vertical-A $(\mathrm{mm})$ & MD:-0.47 (-1.29,0.35) & 0.26 & 2.02 & - \\
\hline 16 & Hanoun 2010 & Sella vertical-Pog $(\mathrm{mm})$ & MD:-1.84 (-3.31,-0.37) & 0.01 & 4.25 & No \\
\hline 17 & Hanoun 2010 & Lower/total anterior face height & MD:-0.01 $(-0.02,0)$ & 0.15 & 0.02 & - \\
\hline 18 & Hanoun 2010 & Sella vertical-1s $(\mathrm{mm})$ & MD:-0.74 (-1.92,0.44) & 0.22 & 3.25 & - \\
\hline 19 & Hanoun 2010 & Sella vertical-1i $(\mathrm{mm})$ & MD:-2.56 (-3.96,-1.16) & $<0.001$ & 2.96 & No \\
\hline 20 & Idris 2018 & N.A.Pog angle $\left({ }^{\circ}\right)$ & MD:-1.48 (-2.69,-0.27) & 0.02 & 2.31 & No \\
\hline 21 & Idris 2018 & S.N.Pog angle $\left(^{\circ}\right)$ & MD:-0.61 (-1.26,0.04) & 0.07 & & - \\
\hline 22 & Idris 2018 & FH-MP angle $\left({ }^{\circ}\right)$ & MD:1.01 (-0.12,2.14) & 0.08 & & - \\
\hline 23 & Idris 2018 & $\mathrm{Y}$-axis angle $\left({ }^{\circ}\right)$ & MD:0.38 (-0.43,1.19) & 0.36 & & - \\
\hline 24 & Idris 2018 & Ar-Go-Me angle $\left(^{\circ}\right)$ & MD:-0.46 (-1.46,0.54) & 0.37 & & - \\
\hline 25 & Idris 2018 & Wits (mm) & MD:0.63 (-0.49,1.75) & 0.27 & & - \\
\hline 26 & Idris 2018 & SN-NL angle $\left({ }^{\circ}\right)$ & MD:-0.82 (-0.91,-0.74) & $<0.001$ & 1.36 & No \\
\hline 27 & Idris 2018 & Cd-Gn (mm) & MD:-1.44 (-3.76,0.88) & 0.22 & & - \\
\hline 28 & Idris 2018 & Go-Pog (mm) & MD:-1.27 (-2.74,0.20) & 0.09 & & - \\
\hline 29 & Idris 2018 & Cd-Go (mm) & MD:-2.18 (-2.85,-1.51) & $<0.001$ & 2.18 & Yes \\
\hline 30 & Idris 2018 & $\mathrm{~N}$-ANS $(\mathrm{mm})$ & MD:-0.98 $(-2.07,0.11)$ & 0.08 & 2.29 & - \\
\hline 31 & Idris 2018 & ANS-PNS (mm) & MD:-0.56 (-2.33,1.21) & 0.54 & 2.15 & - \\
\hline 32 & Idris 2018 & 1s-SN angle $\left({ }^{\circ}\right)$ & MD:0.80 (-1.99,3.59) & 0.57 & 4.19 & - \\
\hline 33 & Idris 2018 & Facial convexity angle $\left({ }^{\circ}\right)$ & MD:-2.59 (-4.27,-0.91) & 0.003 & 2.51 & Yes \\
\hline 34 & Idris 2018 & Nasolabial angle $\left({ }^{\circ}\right)$ & MD:5.79 $(0.82,10.76)$ & 0.02 & 5.17 & Yes \\
\hline 35 & Idris 2018 & Mentolabial angle $\left({ }^{\circ}\right)$ & MD:-5.52 (-12.86,1.82) & 0.14 & 7.72 & - \\
\hline 36 & Idris 2018 & Ls-E line (mm) & MD:-0.30 $(-1.08,0.48)$ & 0.45 & 0.72 & - \\
\hline 37 & Idris 2018 & Li-E line $(\mathrm{mm})$ & MD:0.14 (-0.65,0.93) & 0.73 & 0.80 & - \\
\hline
\end{tabular}

$\mathrm{Cl}$, confidence interval; MD, mean difference; RR, relative risk; SD, standard deviation.

* potentially clinically relevant effect, judged as an effect that is statistically significant $(P<0.05)$ and its effect is at least as big as the minimal clinical important effect: half a standard deviation (combined pre-treatment standard deviation of the two groups) or relative risk $\geq 1.50$ (or $\leq 0.67$ ). 
Table 6. Summary of findings table according to the GRADE approach comparing prefabricated myofunctional appliances with functional appliances.

\begin{tabular}{|c|c|c|c|c|c|c|}
\hline \multirow[b]{2}{*}{$\begin{array}{l}\text { Outcome [follow-up] } \\
\text { Patients (trials) }\end{array}$} & \multirow{2}{*}{$\begin{array}{l}\text { Relative } \\
\text { effect } \\
(95 \% \mathrm{Cl}) \\
\end{array}$} & \multicolumn{3}{|c|}{ Anticipated absolute effects $(95 \% \mathrm{Cl})$} & \multirow{2}{*}{$\begin{array}{l}\text { Quality of the } \\
\text { evidence (GRADE) }\end{array}$} & \multirow{2}{*}{ What happens with PMAs } \\
\hline & & $\begin{array}{l}\text { Functional } \\
\text { appliance }^{a}\end{array}$ & PMA & Difference with PMAs & & \\
\hline $\begin{array}{l}\text { Overjet reduction [ } 6 \text { mos }- \text { Tx end] } \\
184 \text { patients ( } 3 \text { trials) }\end{array}$ & - & $3.5 \mathrm{~mm}$ & - & $\begin{array}{l}1.5 \mathrm{~mm} \text { less } \\
(0.9 \text { to } 2.1 \text { less })\end{array}$ & $\begin{array}{l}\oplus \oplus \bigcirc \bigcirc \text { low }^{c} \\
\text { due to bias }\end{array}$ & $\begin{array}{l}\text { Probably lead to smaller reduction } \\
\text { in overjet }\end{array}$ \\
\hline $\begin{array}{l}\text { Overbite reduction [6-12 mos] } \\
87 \text { patients ( } 2 \text { trials) }\end{array}$ & - & $1.0 \mathrm{~mm}$ & & $\begin{array}{l}0.6 \mathrm{~mm} \text { less } \\
(1.4 \text { less to } 0.1 \text { more })\end{array}$ & $\begin{array}{l}\oplus \oplus \oplus \bigcirc \text { moderate } \\
\text { due to bias }\end{array}$ & $\begin{array}{l}\text { Little to no difference in overbite } \\
\text { reduction }\end{array}$ \\
\hline $\begin{array}{l}\text { Class I molar relationship [Tx end] } \\
97 \text { patients ( } 1 \text { trial) }\end{array}$ & $\begin{array}{l}\text { RR } 0.3 \\
(0.15 \text { to } \\
0.65)\end{array}$ & $45.0 \%$ & $\begin{array}{l}14.0 \% \\
(6.8 \%-29.3 \%)\end{array}$ & $\begin{array}{l}31.0 \% \text { less } \\
(15.7 \% \text { to } 38.2 \% \text { less })\end{array}$ & $\begin{array}{l}\oplus \oplus \oplus \bigcirc \text { moderate }{ }^{\mathrm{d}, \mathrm{e}} \\
\text { due to bias }\end{array}$ & $\begin{array}{l}\text { Probably lead to less patients with } \\
\text { Class I molar relationship }\end{array}$ \\
\hline $\begin{array}{l}\text { ANB reduction [6-12 mos] } \\
87 \text { patients ( } 2 \text { trials) }\end{array}$ & - & $3.2 \mathrm{~mm}$ & - & $\begin{array}{l}1.3 \mathrm{~mm} \text { less } \\
(0.6 \text { to } 2.0 \text { less })\end{array}$ & $\begin{array}{l}\oplus \oplus \oplus \bigcirc \text { moderate } \\
\text { due to bias }\end{array}$ & $\begin{array}{l}\text { Probably lead to smaller reduction } \\
\text { in ANB angle }\end{array}$ \\
\hline $\begin{array}{l}\text { Cd-Go increase [12 mos] } \\
54 \text { patients ( } 1 \text { trial) }\end{array}$ & - & $2.7 \mathrm{mos}$ & - & $\begin{array}{l}2.2 \mathrm{~mm} \text { less } \\
\text { (1.5 to } 2.9 \mathrm{~mm} \text { less) }\end{array}$ & $\begin{array}{l}\oplus \oplus \oplus \bigcirc \text { moderate } \\
\text { due to bias }\end{array}$ & $\begin{array}{l}\text { Probably lead to smaller vertical } \\
\text { development of the ramus }\end{array}$ \\
\hline $\begin{array}{l}\text { Facial convexity reduction [12 mos] } \\
54 \text { patients ( } 1 \text { trial) }\end{array}$ & - & $4.0^{\circ}$ & - & $\begin{array}{l}5.80^{\circ} \text { less } \\
\left(0.8 \text { to } 10.8^{\circ} \text { less }\right)\end{array}$ & $\begin{array}{l}\oplus \oplus \oplus \bigcirc \text { moderate } \\
\text { due to bias }\end{array}$ & Probably lead more convex faces \\
\hline $\begin{array}{l}\text { Total Tx costs [Tx end] } \\
97 \text { patients ( } 1 \text { trial) }\end{array}$ & - & $1548 €$ & - & $\begin{array}{l}574.0 € \text { less } \\
(373.5 \text { to } 774.6 € \text { less })\end{array}$ & $\begin{array}{l}\oplus \oplus \oplus \bigcirc \text { moderate }{ }^{d, f} \\
\text { due to bias }\end{array}$ & $\begin{array}{l}\text { Probably lead to higher treatment } \\
\text { costs }\end{array}$ \\
\hline
\end{tabular}

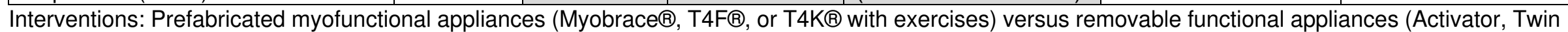

Block) / Population: adolescent patients with any kind of malocclusion / Setting: private practices and university clinics (Malaysia, Sweden, Syria).

a Response in the control group is based on average response of included studies (random-effects meta-analysis).

b Starts from "high"

${ }^{c}$ Downgraded by two levels for bias due to multiple methodological issues.

d Downgraded by one level for bias due to methodological issues.

e Potentially large effect observed $(R R<0.5)$, but no upgrading due to residual confounding.

${ }^{f}$ Potentially large effect observed $(R R<0.5)$, but no upgrading due to residual confounding.

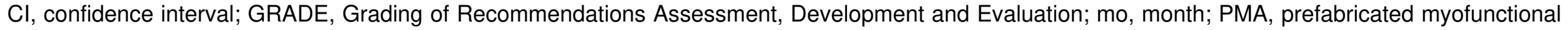
appliance; $\mathrm{RR}$, relative risk; Tx, treatment. 


\section{SUPPLEMENTARY MATERIAL}

Appendix 1. Additional review details and deviations from protocol.

\section{Communications with trialists}

- Dr. A.A. Hanoun was contacted on July $23^{\text {rd }}, 2019$ to request a full-text of his MSc thesis so it can be formally included in the review, since only a preview pdf could be acquired. The same was requested from the thesis supervisor Dr. N. Mokhtar, after Dr. Hanoun suggested so. The full text of the unpublished thesis was ultimately provided via e-mail on August $12^{\text {th }}$.

- Dr. E. Cirgic was contacted on July $25^{\text {th }}, 2019$ to request missing data (age, overbite changes, lip seal changes) and outcome data for either a common timepoint between groups or estimates adjusted for treatment duration (either as aggregate data or the trial's dataset). No response has yet been received.

\section{Additional methods}

- We back-calculated Pre/Post correlation for change in overjet in the PMA group (0.59) and the functional appliance group (0.40) from the Idris 2018 trial that provided both before-and-after data, as well as increments. These Pre/Post correlations were used to calculate overjet increments for the Cirgic 2016 trial.

\section{Deviations from protocol}

- We planned to calculate $95 \%$ random-effects predictions for all meta-analyses with $\geq 3$ trials to aid in their interpretations, but only 2 meta-analyses with 2 trials each were ultimately performed.

- Several factors were planned to be assessed through subgroup analyses/meta-regressions in meta-analyses of at least 5 studies, but could ultimately not be conducted due to limited material/reporting: (i) subsets according to the patient characteristics (patient chronological age, skeletal age, sex, ethnicity, craniofacial configuration, masticatory activity, jaw, baseline malocclusion severity), (ii) subsets according to the different experimental interventions (different 
experimental or control appliances), (iii) subset according to any co-interventions administered, (iv) subsets according to the inclusion of tooth extractions in the treatment plan, and (v) subsets to the treatment provider, including experience each system and status (orthodontist / general dentist).

- We planned to set a significance level of $10 \%$ for tests of between-studies or between-subgroups heterogeneity, but no such analyses were done due to limited studies being included. 
Appendix 2. Literature search strategies for each database, including hits (as of July $25^{\text {th }}, 2019$ ).

\begin{tabular}{|c|c|c|c|}
\hline Database & Search & Limits & Hits \\
\hline MEDLINE & $\begin{array}{l}\text { "prefabricated myofunctional appliance" OR "prefabricated } \\
\text { myofunctional appliances" OR "pre-fabricated myofunctional } \\
\text { appliance" OR "pre-fabricated myofunctional appliances" OR } \\
\text { "prefabricated functional appliance" OR "prefabricated functional } \\
\text { appliances" OR "pre-fabricated functional appliance" OR "pre- } \\
\text { fabricated functional appliances" OR "eruption guidance" OR } \\
\text { "Myobrace" OR "Myo-brace" OR "LM-Activator" OR "Occlusoguide" } \\
\text { OR " Occlus-o-Guide" OR (("Trainer" OR "T4K" OR "T4F") AND } \\
\text { (myofunctional OR "myo-functional")) }\end{array}$ & & 86 \\
\hline Embase & Same as MEDLINE & & 7 \\
\hline CDSR & Same as MEDLINE & & 0 \\
\hline DARE & Same as MEDLINE & & 0 \\
\hline CENTRAL & Same as MEDLINE & & 0 \\
\hline Scopus & $\begin{array}{l}\text { TITLE-ABS-KEY ( "prefabricated myofunctional appliance" OR } \\
\text { "prefabricated myofunctional appliances" OR "pre-fabricated } \\
\text { myofunctional appliance" OR "pre-fabricated myofunctional } \\
\text { appliances" OR "prefabricated functional appliance" OR } \\
\text { "prefabricated functional appliances" OR "pre-fabricated functional } \\
\text { appliance" OR "pre-fabricated functional appliances" OR "eruption } \\
\text { guidance appliance" OR "Myobrace" OR "Myo-brace" OR "LM- } \\
\text { Activator" OR "Occlusoguide" OR " Occlus-o-Guide" OR ( ( "Trainer" } \\
\text { OR "T4K" OR "T4F" ) AND ( myofunctional OR "myo-functional" ) ) ) }\end{array}$ & Dentistry & 34 \\
\hline WOK & Same as MEDLINE & $\begin{array}{l}\text { DENTISTRY ORAL } \\
\text { SURGERY MEDICINE }\end{array}$ & 28 \\
\hline VHL & Same as MEDLINE & & 13 \\
\hline WHO trials & myofunctional & & 19 \\
\hline
\end{tabular}

CDSR, Cochrane Database of Systematic Reviews; CENTRAL, Cochrane Central Register of Controlled Trials; DARE, Cochrane Database of Abstracts of Reviews of Effects; VHL, Virtual Health Library; WHO, World Health Organisation; WOK, Web of Knowledge. 
Appendix 3. List of studies identified from the literature search and their inclusion/exclusion status, with reasons. $\mathrm{Nr} /$ Pape

\{JPRN-UMIN000011171\} Pilot Study for ORAI myofunctional CLinical Evidence: elderly\} 11/07/2013". Not recruiting.

\{JPRN-UMIN000011488\} Pilot Study for ORAI myofunctional CLinical Evidence: dementia\} 14/08/2013". Not recruiting.

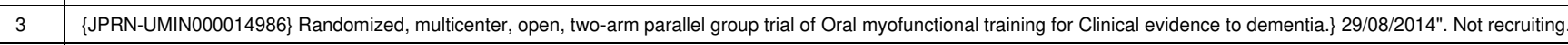

\{JPRN-UMIN000016594\} Oral myofunctional training trial for CLinical Evidence-Learning disabilities\} 21/02/2015". Not recruiting.

$5 \quad$ \{JPRN-UMIN000027547\} Impact of self oral myofunctional theraphy in the patients of obstructive sleep apnea syndrome\} 30/05/2017". Recruiting.

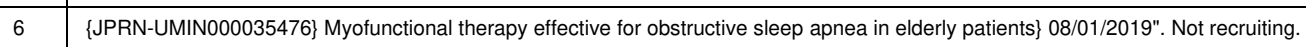

\begin{tabular}{l|l}
7 & $\{$ NCT00989209\} Myofunctional Therapy in Facial Palsy $\}$ 02/10/2009". Not recruiting.
\end{tabular}

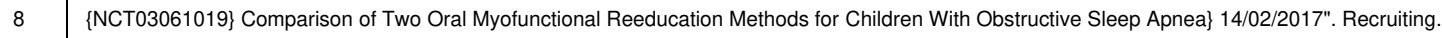

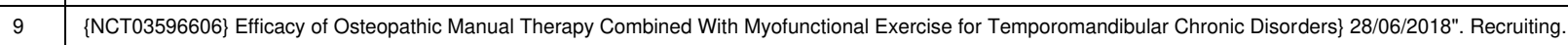

$10 \quad$ \{RBR-4mt6yr\} Effects of speech therapy on chewing of individuals who underwent surgery to correct an imbalance in facial pattern\} 10/05/2016". Not recruiting.

11 Alves TP, Soares TR, Barreto SC, Fried H, Pereira GD, Maia LC, et al. Multidisciplinary approach for the treatment of extensive external cervical resorption after dental trauma. Oper Dent. 2013;38(4):349-57.

12 Baek SH, Park YH, Chung JH, Kim S, Choi JY. Orthodontic and orthopedic treatment for a growing patient with Tessier number 0 cleft. Korean J Orthod. 2018;48(2):113-24.

13 Braun C, Henneberger G, Racenberg E. [Techniques of continuous nerve block at the level of the wrist]. Ann Chir Main Memb Super. 1992;11(2):141-5.

$14 \quad$ Brin I, Ben-Bassat Y, Zilberman Y, Fuks A. Effect of trauma to the primary incisors on the alignment of their permanent successors in Israelis. Community Dent Oral Epidemiol.

14 1988;16(2):104-8.

15 Cheng AC, Tee-Khin N, Siew-Luen C, Lee H, Wee AG. The management of a sever

16 Condo R, Perugia C, Bartolino M, Docimo R. Analysis of clinical efficacy of interceptive treatment of Class II division 2 malocclusion in a pair of twins through the use of two modified removable appliances. Oral Implantol (Rome). 2010;3(3):11-25.

$17 \begin{aligned} & \text { Croft RS, Buschang } \\ & 1999 ; 116(4): 435-43\end{aligned}$

$18 \quad$ Ebato A, Suzuki H, Sakamaki T, Ooguchi S, Chow CM, Komiyama O. Obstructive sleep apnea treatment with a twopiece mandibular advancement device with an elastic retention band in combination with orofacial myofunctional therapy: A case report. Sleep Science. 2019;12(1):57-60. 19 Epstein DD, Epstein PL, Cohen BI, Pagnillo MK. Comparison of the retentive properties of six prefabricated post overdenture attachment systems. J Prosthet Dent. 1999;82(5):579-

20 Flesch I. [Augmentation with antibiotic-impregnated spacers in sepsis revision surgery]. Unfallchirurg. 2015;118(10):844-50.

21 Freitas FCNd, Castro Ld, Bittencourt LP, Moraes APd, Bastos E. Aparelho Guia de Erupçäo na interceptaçäo da sobremordida profunda: relato de caso. $J$ bras ortodon ortop facial. 1999:4(19):29-34.

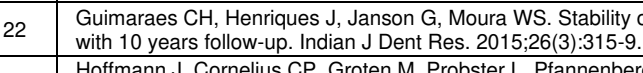

23 Hoffmann J, Cornelius CP, Groten M, Probster L, Pfannenberg C, Schwenzer N. Orbital reconstruction with individually copy-milled ceramic implants. Plast Reconstr Surg . 1998;101(3):604-12.

$24 \quad \begin{aligned} & \text { Hoffmann J, Cornelius CP, Groten M, P } \\ & \text { Gesichtschir. 1998;2 Suppl 1:S98-101. }\end{aligned}$ $\begin{array}{ll}25 & \text { James AM, Williams CM, Haines TP. Effectiveness of footwear and foot orthoses for calcaneal apophysitis: a 12-month factorial randomised trial. Br J Sports Med. } \\ 2016 ; 50(20): 1268-75 .\end{array}$

26 Jankulovska V, Chuchkova GK. Minimally invasive orthodontics in treatment of malocclusion class III: Case reports. Acta Stomatologica Croatica. 2016;50(1):95.

27 Janson G. Eruption guidance appliance effects - In response. American Journal of Orthodontics and Dentofacial Orthopedics. 2000;118(2):11A-A.

28 Katrana F, Kostopoulos E, Delia G, Lunel GG, Casoli V. Reanimation of thumb extension after upper extremity degloving injury treated with Integra. J Hand Surg Eur Vol. 2008;33(6):800-2.

29 Kim TW, Park JH. Eruption guidance in the mixed dentition: a case report. J Clin Pediatr Dent. 2008;32(4):331-9.

30 Kizi G, Barata R, Ribas D, Castaño Seiquer A, Ventura I. Early treatment of a class III malocclusion with the myobrace system: Clinical case. Annals of Medicine. 2018;50:S92-S3.

$31 \quad$ Krakowxzyk L, Maciejewski A, Szymczyk C, Grajek M, Stobiecka E, Poltorak S. Flap prefabrication using high-density porous polyethylene in an animal model - an experimental study. Med Sci Monit Basic Res. 2013;19:210-3.

32 Kupeyan HK, Shaffner M, Armstrong J. Definitive CAD/CAM-guided prosthesis for immediate loading of bone-grafted maxilla: a case report. Clin Implant Dent Relat Res.

32 2006;8(3):161-7.

33 Lagana G, Cozza P. Interceptive therapy with elastodontic appliance: case report. Ann Stomatol (Roma). 2010;1(3-4):22-8.

34 Ledingham WM, Wytch R, Goring CC, Mathieson AB, Wardlaw D. On immediate functional bracing of Colles' fracture. Injury. 1991;22(3):197-201.

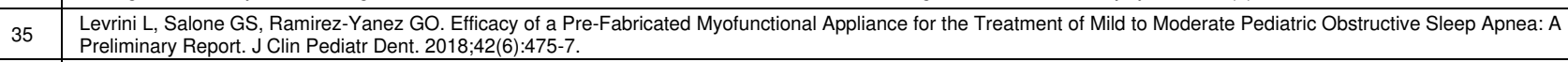

36 Levrini L, Salone GS, Ramirez-Yanez GO. Pre-Fabricated Myofunctional Appliance for the Treatment of Mild to Moderate Pediatric Obstructive Sleep Apnea: A Preliminary Report. $\mathrm{J}$ Clin Pediatr Dent. 2018;42(3):236-9.

37 Luo J, Morrison DA, Hayes AJ, Bala A, Watts G. Single-Piece Titanium Plate Cranioplasty Reconstruction of Complex Defects. J Craniofac Surg. 2018;29(4):839-42.

38 Malivukovic A, Novakovic N, Lepic M, Minic L, Stepic N, Dordevic B, et al. Cranial reconstruction with prefabricated 3D implant after a gunshot injury: A case report. Vojnosanit Pregl. 2016;73(8):783-7.

39 McArdle BF. Using a fixed provisional prosthesis during post-extraction healing and implant placement. Compend Contin Educ Dent. 2006;27(3):179-84; quiz 85, 95.

40 Moir JS, Murali SR, Ashcroft GP, Wardlaw D, Matheson AB. A new functional brace for the treatment of Colles' fractures. Injury. 1995;26(9):587-93.

41 Morisaki I, Hashida S, Mihara J, Takagaki M, Sobue S. Complete root resorption of an upper central incisor due to ectopic eruption of canine in a deaf-mute child. J Osaka Univ

41 Dent Sch. 1990;30:148-52.

42 Nergiz I, Arpak N, Bostanci H, Scorziello TM, Schmage P. Stability of loaded and unloaded implants with different surfaces. Int J Oral Maxillofac Implants. 2009;24(2):289-98.

43 Nkenke E, Agaimy A, Vairaktaris E, Lell M, von Wilmowsky C, Eitner S. Case History Report: Immediate Rehabilitation with a Prefabricated Fibula Flap Following Removal of a Locally Aggressive Maxillary Tumor. Int J Prosthodont. 2016;29(1):53-8.

44 O'Sullivan AD, Wicke D, Hengen TJ, Sieverding HL, Stone JJ. Life Cycle Assessment modelling of stormwater treatment systems. J Environ Manage. 2015;149:236-44. \begin{tabular}{ll}
45 & $\begin{array}{l}\text { Pompeia LE, Rossetti RM, Faria PR, Ortolani CLF, Junior KF. Tratamento de mordida aberta anterior com terapia miofuncional relato de caso. Ortho Sci, Orthod sci pract. } \\
2017 ; 10(37): 75-81 .\end{array}$ \\
\hline 46 & R
\end{tabular}

46 Ramirez-Yanez GO, Faria P. Early treatment of a Class II, division 2 malocclusion with the Trainer for Kids (T4K): a case report. J Clin Pediatr Dent. 2008;32(4):325-9. $\begin{array}{ll}47 & \begin{array}{l}\text { Reich W, Seidel D, Bredehorn-Mayr T, Eckert AW. [Reconstruction of isolated orbital floor fractures with a prefabricated titanium mesh]. Klin Monbl Augenheilkd. 2014;231(3):246- } \\ 55 .\end{array}\end{array}$

48 Romanos GE, May S, May D. Treatment concept of the edentulous mandible with prefabricated telescopic abutments and immediate functional loading. Int J Oral Maxillofac

Implants. 2011;26(3):593-7.

49 Rustemeyer J, Dicke U. Prefabricated nerve conduits advance histomorphological and functional outcomes in nerve regeneration of the sciatic nerve of the rat. Int $\mathrm{J}$ Oral Maxillofac 49 Surg. 2010;39(9):889-96.

$50 \quad$ Stern EB. Wrist extensor orthoses: dexterity and grip strength across four styles. Am J Occup Ther. 1991;45(1):42-9.

51 Vinci P, Gargiulo P. Poor compliance with ankle-foot-orthoses in Charcot-Marie-Tooth disease. Eur J Phys Rehabil Med. 2008;44(1):27-31.

52 Wahl G, Lang H. Deformation at the implant interface to prosthetic superstructure: an interferometric approach. Clin Oral Implants Res. 2004;15(2):233-8.

\section{Status}

Exclusion by title

Exclusion by title

Exclusion by title

Exclusion by title

Exclusion by title

Exclusion by title

Exclusion by title

Exclusion by title

Exclusion by title

Exclusion by title

Exclusion by title

Exclusion by title

Exclusion by title

Exclusion by title

Exclusion by title

Exclusion by title

Exclusion by title

Exclusion by title

Exclusion by title

Exclusion by title

Exclusion by title

Exclusion by title

Exclusion by title

Exclusion by title

Exclusion by title

Exclusion by title

Exclusion by title

Exclusion by title

Exclusion by title

Exclusion by title

Exclusion by title

Exclusion by title

Exclusion by title

Exclusion by title

Exclusion by title

Exclusion by title

Exclusion by title

Exclusion by title

Exclusion by title

Exclusion by title

Exclusion by title

Exclusion by title

Exclusion by title

Exclusion by title

Exclusion by title

Exclusion by title

Exclusion by title

Exclusion by title

Exclusion by title

Exclusion by title

Exclusion by title

Exclusion by title 
53 Wang CH, Lee HE. [Stress distribution of prefabricated screw posts. Part II: Different designs and materials]. Gaoxiong Yi Xue Ke Xue Za Zhi. 1991;7(11):590-8.

54 Wilmes B, Vasudavan S, Drescher D. CAD-CAM-fabricated mini-implant insertion guides for the delivery of a distalization appliance in a single appointment. Am J Orthod

55 Yukun L, Ke G, Jiaming S. Application of Nipple Retractor for Correction of Nipple Inversion: A 10-Year Experience. Aesthetic Plast Surg. 2016;40(5):707-15.

$56 \quad$ \{RBR-5hhtrt\} Efficiency of muscle training with visual support for swallowing in the elderly\} 01/02/2018". Recruiting.

57 Grillo E, Curr F, Salvadori S, Vigan VM, Giannini L, Farronato G. Use of elastodontic appliances: A case report. Mondo Ortodontico. 2012;37(4):135-40.

58 Al-Sulaita N, White GE. Orthopedic approach in the treatment of a skeletal class II division 1 malocclusion with an anterior open bite. J Clin Pediatr Dent. 2005;29(3):205-10.

59 Barone S, Neri P, Paoli A, Razionale AV. Design and manufacturing of patient-specific orthodontic appliances by computer-aided engineering techniques. Proc Inst Mech Eng H.

$59 \quad 2018 ; 232(1): 54-66$.

60 Gujjar KR, Indushekar KR, Amith HV, Sharma SL. Modified distal shoe appliance--fabrication and clinical performance. J Dent Child (Chic). 2012;79(3):185-8.

61 Ierardo G, Luzzi V, Nardacci G, Vozza I, Polimeni A. Minimally invasive orthodontics: elastodontic therapy in a growing patient affected by Dentinogenesis Imperfecta. Ann Stomatol (Roma). 2017;8(1):34-8.

62 Kleinerman V, Bergersen EO. Preventive and interceptive orthodontics for the 5 to 12 year-old. Functional appliances: the Nite-Guide and Occlus-o-Guide techniques. Refuat Hapeh Vehashinayim (1993). 2011;28(2):8-18, 72

63 Mahony D. Combining functional appliances in the straightwire system. J Clin Pediatr Dent. 2002;26(2):137-40.

64 Pae EK. Response of masticatory muscles to passive stretch stimulus - from perspectives of functional appliances. Korean J Orthod. 2012;42(2):64-72.

65 Pietila I, Pietila T, Pirttiniemi P, Varrela J, Alanen P. Orthodontists' views on indications for and timing of orthodontic treatment in Finnish public oral health care. Eur J Orthod. 2008;30(1):46-51.

66 Sood S, Kharbanda OP, Duggal R, Sood M, Gulati S. Muscle response during treatment of Class II Division 1 malocclusion with Forsus Fatigue Resistant Device. J Clin Pediatr Dent. 2011;35(3):331-8.

67 Tatara AM, Wong ME, Mikos AG. In vivo bioreactors for mandibular reconstruction. J Dent Res. 2014;93(12):1196-202.

68 Tripathi NB, Patil SN. Treatment of class II division 1 malocclusion with myofunctional trainer system in early mixed dentition period. J Contemp Dent Pract. 2011;12(6):497-500.

69 Wang X, Zhang JJ, Yuan FS, Wang Y, Li CH, Varrela JE, et al. [Three-dimensional analysis of the early correction of anterior crossbite using eruption guidance appliance]. Beijing 69 Da Xue Xue Bao Yi Xue Ban. 2018;50(3):532-7.

70 Dainesi EA, Kawauchi MY, Roberto AFB. Correção precoce da sobremordida profunda com aparelho guia de erupção. Ortho Sci, Orthod sci pract. 2016;9(35):114-20.

71 Guarim JdA. Avaliação do crescimento mandibular em um respirador bucal após o tratamento com o uso dos aparelhos ortopédico pré-fabricados. Rev paul odontol. 2010;32(2):26-33

72 Guimarães Junior CH, Pinto AS. Aparelho miofuncional para guia de erupção. J bras ortodon ortop facial. 2000;5(26):42-6.

73 Santos-Pinto PRd, Sanrtos-Pinto CCmd, Gandini LG, Santos-Pinto Ad, Pizol KDCE, Santos-Pinto Nd. Correção da má oclusão de Classe II com mordida profunda utilizando o

73 aparelho guia de irrupção Oclus-o-guide. Rev clín ortodon Dental Press. 2009;8(3):91-100.

74 Methenitou S, Shein B, Ramanathan G, Bergersen EO. Prevention of overbite and overjet development in the 3 to 8 year old by controlled nighttime guidance of incisal eruption: a study of 43 individuals. J Pedod. 1990;14(4):219-30.

75 Pereira ACJ. Avaliação cefalométrica dos efeitos do Guia de Erupção no tratamento da má oclusão de Classe II, 1ª Divisão, após 10 meses, em jovens brasileiros, com idade média de 9 anos. 1995:151-.

76 Silva CCAd. Avaliação cefalométrica dos efeitos do aparelho Guia de Erupção no tratamento da má oclusão de classe II, divisão 1, após dois anos. 1997:175-.

77 Souza JEPd. Comparação da proporção de sucesso de três modalidades de tratamento ortodôntico: Frankel, Occlus-O-Guide e fixo, na correção da classe II. 2001:150-.

78 Bassigny F. [Early treatment of severe dento-maxillary dysharmony: eruption guidance of incisors and canines]. Rev Orthop Dento Faciale. 1990;24(2):191-218.

79 Bergersen EO. Preventive and interceptive orthodontics in the mixed dentition with the myofunctional eruption guidance appliance: correction of crowding, spacing, rotations, crossbites, and TMJ. J Pedod. 1988;12(4):386-414

80 Bergersen EO. Preventive and interceptive orthodontics in the mixed dentition with the myofunctional eruption guidance appliance: correction of overbite and overjet. J Pedod.

$80 \quad 1988 ; 12(3): 292-324$.

81 Bergersen EO. The eruption guidance myofunctional appliance in the consecutive treatment of malocclusion. Gen Dent. 1986;34(1):24-9.

82 Bergersen EO. The eruption guidance myofunctional appliance: case selection, timing, motivation, indications and contraindications in its use. Funct Orthod. 1985;2(1):17-21, 4-5, 8-33.

83 Bergersen EO. The eruption guidance myofunctional appliances: how it works, how to use it. Funct Orthod. 1984;1(3):28-9, 31-5.

84 Little RM. The effects of eruption guidance and serial extraction on the developing dentition. Pediatr Dent. 1987;9(1):65-70.

85 \{NCT03863275\} Analysis of Muscle Activity With Myofunctional Devices, Using Surface Electromyography\} 22/02/2019". Not recruiting.

86 Varrela J, Keski-Nisula K, Keski-Nisula L, Lehto R. Effects of orthodontic intervention with eruption guidance appliance in early mixed dentition. Journal of Dental Research.

86 2003;82:B374-B.

87 Wishney M, Darendeliler MA, Dalci O. Myofunctional therapy and prefabricated functional appliances: an overview of the history and evidence. Aust Dent J. 2019;64(2):135-44.

88 Ricciardi C, Cagetti MG, Cattaneo S, Qing Hu Y, Strohmenger L. Interceptive orthodontic treatment with elastomeric appliances: Literature review and case reports. Dental Cadmos.

$88 \quad 2017 ; 85(3): 146-54$.

89 Ahn ES, Kim AH, Shim YS, An SY. Oropharyngeal Airway Three-dimensional Changes after Treatment with Myobrace in Class II Retrognathic Children. Iran J Public Health.

2017;46(2):265-7.

$90 \quad$ King RK. Eruption guidance appliance effects. Am J Orthod Dentofacial Orthop. 2000;118(2):11a.

91 Migliaccio S, Aprile V, Zicari S, Grenci A. Eruption guidance appliance: a review. Eur J Paediatr Dent. 2014;15(2):163-6.

92 Reukers HA, Bartzela T. [Orthodontics in general practice. 4. Eruption guidance appliances in orthodontics]. Ned Tijdschr Tandheelkd. 2008;115(3):133-6.

93 Dinkova M. Vertical control of overbite in mixed dentition by trainer system. Journal of IMAB - Annual Proceeding (Scientific Papers). 2014;20(5):648-54.

94 Bergersen EO. Preventive eruption guidance in the 5-to-7-year-old. J Clin Orthod. 1995;29(6):382-95.

95 \{ChiCTR1800016467\} A study about the periodontal condition of patients with mouth breathing after wearing myofunctional appliance\} 2018-06-02". Recruiting.

96 \{ISRCTN20400513\} The effectiveness of an orthodontic brace for a receding chin\} 12/06/2013". Not recruiting.

$97 \quad$ \{JPRN-UMIN000032179\} Effect of myofunctional therapy on subjects with lip incompetence - Multimodality analysis\} 10/04/2018". Recruiting

$98 \quad$ \{JPRN-UMIN000036005\} Effect of muscular function therapy on tongue thrust- Investigation by multi modality analysis\} 25/02/2019". Recruiting.

99 \{RBR-728mj2\} Evaluation of the development of chewing, breathing, speech and swallowing functions in children with sucking habit\} 22/11/2018". Not recruiting.

Exclusion by title

Exclusion by title

Exclusion by title

Exclusion by

abstract

Exclusion by

abstract

Exclusion by

abstract

Exclusion by

abstract

Exclusion by

abstract

Exclusion by

abstract

Exclusion by

abstract

Exclusion by

abstract

Exclusion by

abstract

Exclusion by

abstract

Exclusion by

abstract

Exclusion by

abstract

Exclusion by

abstract

Exclusion by

abstract

Exclusion by

abstract

Exclusion by

abstract

Exclusion by

abstract

Excluded;

missing fulltext

Excluded;

missing fulltex

Excluded;

missing fulltex

Excluded;

missing fulltext

Excluded;

missing fulltext

Excluded;

missing fulltex

Excluded;

missing fulltext

Excluded;

Excluded;
missing fulltext

Excluded;

missing fulltext

Excluded;

missing fulltex

Excluded;

ongoing study

Excluded

conference

proceeding

Excluded; review

Excluded; review

Excluded; no

clinical study

Excluded; no

clinical study

Excluded; no

clinical study

Excluded; no

clinical study

Excluded; case

report/series

Excluded; case

report/series

Excluded; no

longitudinal

study

Excluded; no

myofunctional

appliance

Excluded; no

myofunctional

appliance

Excluded; no

myofunctional

appliance

axpliance

Excluded; no
myofunctional

appliance 

Quintella C, Martins DR, Janson G. Avaliação da influência do guia de erupção occlus-o-guide, nos incisivos superiores e inferiores, com rizogênese incompleta. Ortodontia.
2004;37(1):50-6.

$106 \quad$ Chalipa J, Ghajari F,

Janson G, Nakamura A, Chiqueto K, Castro R, de Freitas MR, Henriques JF. Treatment stability with the eruption guidance appliance. Am J Orthod Dentofacial Orthop.

2007;131(6):717-28

108

Myrlund R, Keski-Nisula K, Kerosuo H. Stability of orthodontic treatment outcomes after 1-year treatment with the eruption guidance appliance in the early mixed dentition: A followup study. Angle Orthod. 2019;89(2):206-13.

Suzuki H, Watanabe A, Akihiro Y, Takao M, Ikematsu T, Kimoto S, et al. Pilot study to assess the potential of oral myofunctional therapy for improving respiration during sleep. J Prosthodont Res. 2013;57(3):195-9

110 \{ACTRN12610000767000\} Myofunctional therapy in predominant mouth breathers\} 15/09/2010". Not recruiting.

111 Nilsson JJ, Shu X, Magnusson BH, Burt IA. Treatment of adolescent patients with class II division 1 malocclusion using Eruption guidance appliance: A comparative study with Twin-block and Activator-Headgear appliances. Swed Dent J. 2016;40(1):79-89.

112 \begin{tabular}{l|l} 
Farro \\
6.
\end{tabular} Farronato G, Giannini L, Galbiati G, Grillo E, Maspero C. Occlus-o-Guide® versus Andresen activator appliance: Neuromuscular evaluation. Progress in Orthodontics. 2013;14(1):1Janson G, de Souza JE, de Freitas MR, Henriques JF, Cavalcanti CT. Occlusal changes of Class II malocclusion treatment between Frankel and the eruption guidance appliances. Angle Orthod. 2004;74(4):521-5.

Janson G, Nakamura A, de Freitas MR, Henriques JF, Pinzan A. Apical root resorption comparison between Frankel and eruption guidance appliances. Am J Orthod Dentofacial

114 Jansop. 2007:131(6):729-35.

115 Janson GR, da Silva CC, Bergersen EO, Henriques JF, Pinzan A. Eruption Guidance Appliance effects in the treatment of Class II, Division 1 malocclusions. Am J Orthod Dentofacial Orthop. 2000;117(2):119-29.

116 Atik E, Gorucu-Coskuner H, Kocadereli I. Dentoskeletal and airway effects of the X-Bow appliance versus removable functional appliances (Frankel-2 and Trainer) in prepubertal Class II division 1 malocclusion patients. Aust Orthod J 2017;33(1):3-1

117 Janson GR, Pereira AC, Bergersen EO, Henriques JF, Pinzan A, de Almeida RR. Cephalometric evaluation of the eruption guidance appliance in Class II, division 1 treatment. J Clin Orthod. 1997;31(5):299-306.

Keski-Nisula K, Hernesniemi R, Heiskanen M, Keski-Nisula L, Varrela J. Orthodontic intervention in the early mixed dentition: a prospective, controlled study on the effects of the

118 eruption guidance appliance. Am J Orthod Dentofacial Orthop. 2008;133(2):254-60; quiz 328.e2.

119 Keski-Nisula K, Keski-Nisula L, Salo H, Voipio K, Varrela J. Dentofacial changes after orthodontic intervention with eruption guidance appliance in the early mixed dentition. Angle Orthod. 2008;78(2):324-31.

Mummolo S, Tieri M, Tecco S, Mattei A, Albani F, Giuca MR, et al. Clinical evaluation of salivary indices and levels of Streptococcus mutans and Lactobacillus in patients treated with Occlus-o-Guide. Eur J Paediatr Dent. 2014;15(4):367-70.

Ramirez-Yanez G, Sidlauskas A, Junior E, Fluter J. Dimensional changes in dental arches after treatment with a prefabricated functional appliance. J Clin Pediatr Dent. 2007;31(4):279-83.

Usumez S, Uysal T, Sari Z, Basciftci FA, Karaman Al, Guray E. The effects of early preorthodontic trainer treatment on Class II, division 1 patients. Angle Orthod. 2004;74(5):605-9.

. The effects of myofunctional appliance treatment on the perioral and masticatory muscles in Class II, Division 1 patients. World $J$ Orthod. 2010;11(2):117-22.

126 Cirgic E. Treatment of large overjet in preadolescents. Studies of treatment effects, cost assessment and patient perceptions- a comparison of two removable functional appliances. Doctoral Dissertation, University of Gotheburg, 2017.

127 Cirgic E, Kjellberg H, Hansen K. Discomfort, expectations, and experiences during treatment of large overjet with Andresen Activator or Prefabricated Functional Appliance: a questionnaire survey. Acta Odontol Scand. 2017;75(3):166-72.

128 Cirgic E, Kjellberg H, Hansen K. Treatment of large overjet in Angle Class

Included

Included

Included

Cirgic E, Kjellberg H, Petzold M, Hansen K. A cost-minimization analysis of large overjet reduction with two removable functional appliances based on a randomized controlled trial. Eur J Orthod. 2018;40(4):437-43.

130 Idris G, Hajeer MY, Al-Jundi A. Soft- and hard-tissue changes following treatment of Class II division 1 malocclusion with Activator versus Trainer: a randomized controlled trial. Eur J Orthod. 2019;41(1):21-8.

31 Myrlund R, Dubland M, Keski-Nisula K, Kerosuo H. One year treatment effects of the eruption guidance appliance in 7- to 8-year-old children: a randomized clinical trial. Eur J Orthod. 2015;37(2):128-34

132 Hanoun AA. The Efficacy Of The Prefabricated T4FTM Myofunctional Appliance In Comparison To Twin Block Appliance For Class II Division 1 Malocclusion Treatment: A Randomized Clinical Trial. MSc Thesis, University Sains Malaysia, 2010.

\section{$\mathrm{SD}$, standard deviation.}


Appendix 4. Detailed assessment of included randomised trials with the RoB 2.0 tool (supplement to Table 2).

\begin{tabular}{|c|c|c|c|c|c|}
\hline Domain & Reference & Cirgic 2015 & Hanoun 2010 & Idris 2018 & Myrlund 2015 \\
\hline \multirow{4}{*}{$\begin{array}{l}\text { 1. Randomisation } \\
\text { process }\end{array}$} & 1.1 & PY & $\mathrm{Y}$ & $\bar{Y}$ & $\mathrm{Y}$ \\
\hline & 1.2 & PY & $\mathrm{Y}$ & $\mathrm{Y}$ & $\mathrm{Y}$ \\
\hline & 1.3 & PY & $\mathrm{N}$ & $\mathrm{N}$ & $\mathrm{PN}$ \\
\hline & Judgement & Some concerns & Low & Low & Low \\
\hline \multirow{8}{*}{$\begin{array}{l}\text { 2. Deviations } \\
\text { from intended } \\
\text { interventions }\end{array}$} & 2.1 & $\mathrm{Y}$ & $\mathrm{Y}$ & $\mathrm{Y}$ & $\mathrm{Y}$ \\
\hline & 2.2 & $\mathrm{Y}$ & $\bar{Y}$ & $\bar{Y}$ & $Y$ \\
\hline & 2.3 & PY & PN & PN & PN \\
\hline & 2.4 & PY & NA & NA & NA \\
\hline & 2.5 & PN & NA & NA & NA \\
\hline & 2.6 & PY & $\mathrm{Y}$ & $\mathrm{Y}$ & $Y$ \\
\hline & 2.7 & NA & NA & NA & NA \\
\hline & Judgement & High & Low & Low & Low \\
\hline \multirow{5}{*}{$\begin{array}{l}\text { 3. Mising } \\
\text { outcome data }\end{array}$} & 3.1 & $\mathrm{Y}$ & PN & PY & PY \\
\hline & 3.2 & NA & PY & NA & NA \\
\hline & 3.3 & NA & NA & NA & NA \\
\hline & 3.4 & NA & NA & NA & NA \\
\hline & Judgement & Low & Low & Low & Low \\
\hline \multirow{6}{*}{$\begin{array}{l}\text { 4. Measurement } \\
\text { of the outcome }\end{array}$} & 4.1 & $\mathrm{~N}$ & $\mathrm{~N}$ & $\mathrm{~N}$ & $\mathrm{~N}$ \\
\hline & 4.2 & PN & $\mathrm{N}$ & $\mathrm{N}$ & $\mathrm{PN}$ \\
\hline & 4.3 & $\mathrm{Y}$ & $\mathrm{N}$ & PY & $\mathrm{N}$ \\
\hline & 4.4 & PY & NA & PY & NA \\
\hline & 4.5 & PY & NA & $\mathrm{NI}$ & NA \\
\hline & Judgement & High & Low & High & Low \\
\hline \multirow{4}{*}{$\begin{array}{l}\text { 5. Selection of } \\
\text { the reported } \\
\text { result }\end{array}$} & 5.1 & $\mathrm{NI}$ & $\mathrm{NI}$ & $\mathrm{NI}$ & $\mathrm{NI}$ \\
\hline & 5.2 & PY & PN & $\mathrm{N}$ & $\mathrm{N}$ \\
\hline & 5.3 & $\mathrm{Y}$ & PN & $\mathrm{N}$ & $\mathrm{N}$ \\
\hline & Judgement & High & Some concerns & Some concerns & Some concerns \\
\hline Overall & Judgement & High & Some concerns & High & Some concerns \\
\hline
\end{tabular}

